Cover Photo: Antioch Dunes National Wildlife Refuge sand dune habitat with Antioch Evening Primrose (Oenothera deltoides subsp. howellii). Photograph taken by S. Jones, May 2019, U.S. Geological Survey. 


\section{Distribution, Abundance, and Genomic Diversity of the Endangered Antioch Dunes Evening Primrose (Oenothera deltoides subsp. howellii) Surveyed in 2019}

Edited by Karen M. Thorne and Amy G. Vandergast

Prepared in cooperation with the U.S. Fish and Wildlife Service and the Friends of San Pablo Bay National Wildlife Refuge

Open-File Report 2021-1017 


\section{U.S. Geological Survey, Reston, Virginia: 2021}

For more information on the USGS - the Federal source for science about the Earth, its natural and living resources, natural hazards, and the environment—visit https://www.usgs.gov or call 1-888-ASK-USGS.

For an overview of USGS information products, including maps, imagery, and publications, visit https://store.usgs.gov/.

Any use of trade, firm, or product names is for descriptive purposes only and does not imply endorsement by the U.S. Government.

Although this information product, for the most part, is in the public domain, it also may contain copyrighted materials as noted in the text. Permission to reproduce copyrighted items must be secured from the copyright owner.

Suggested citation:

Thorne, K.M., and Vandergast, A.G., 2021, Distribution, abundance, and genomic diversity of the endangered Antioch Dunes evening-primrose (Oenothera deltoides subsp. howellii) surveyed in 2019: U.S. Geological Survey Open-File Report 2021-1017, 40 p., https://doi.org/10.3133/ofr20211017.

ISSN 2331-1258 (online) 


\section{Contents}

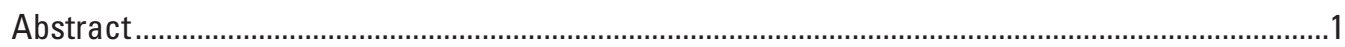

Chapter A. Distribution and Abundance of the Endangered Antioch Dunes

Evening-Primrose (Oenothera deltoides subsp. howellii) .....................................................2

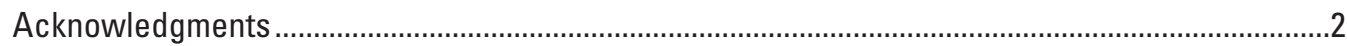

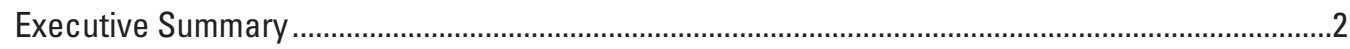

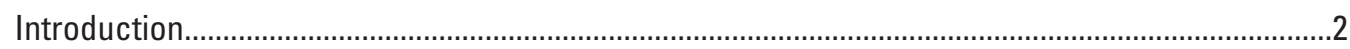

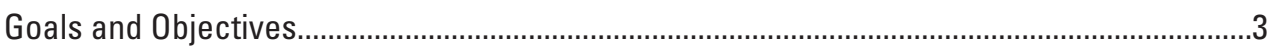

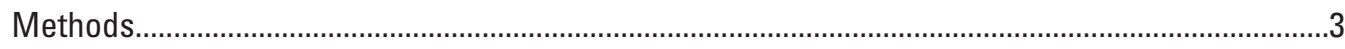

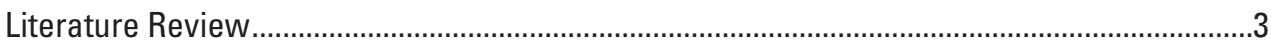

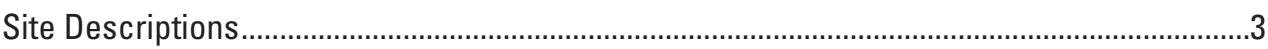

Howellii Distribution and Abundance...............................................................................

Howellii Spatial Ecology ...................................................................................................

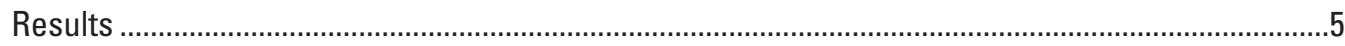

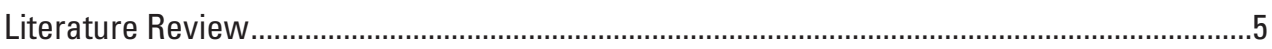

Howellii Distribution and Abundance .....................................................................................



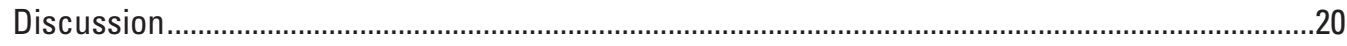

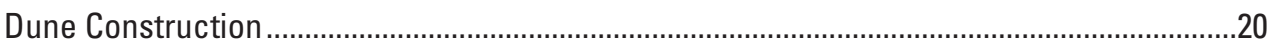

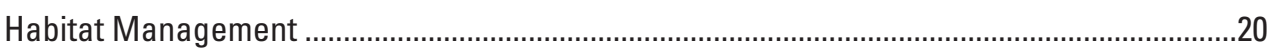

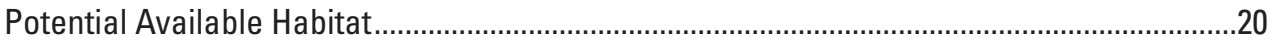

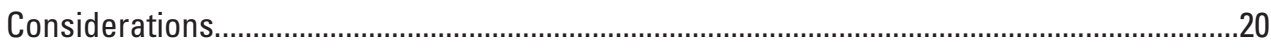

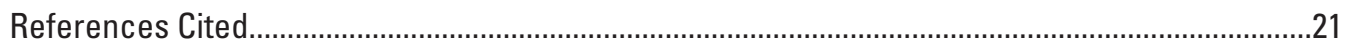

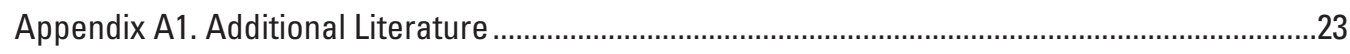

Appendix A2. Shapefiles of Individual Leica Real-Time Kinematic Global Positioning

Chapter B. Population Genomic Structure of the Endangered Antioch Dunes Evening-Primrose (Oenothera deltoides subsp. howellii) and Detection of a

Potentially New Oenothera deltoides Taxon in Contra Costa County, California .................24

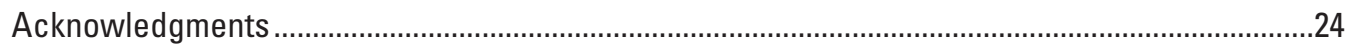

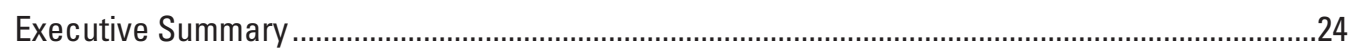

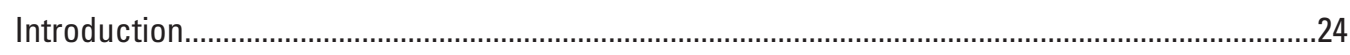

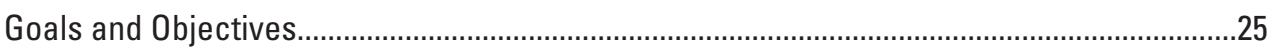

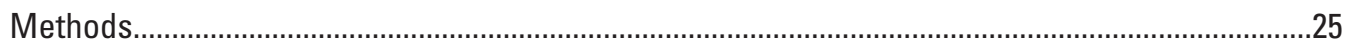



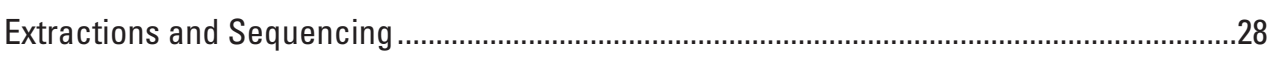

Bioinformatics and Population Genomic Analyses...........................................................28

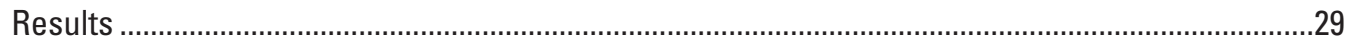

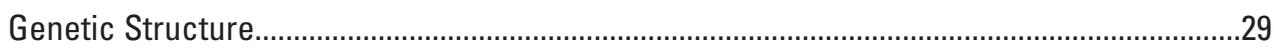

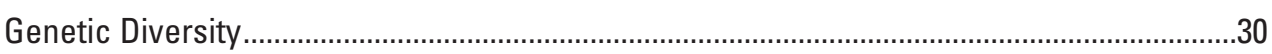

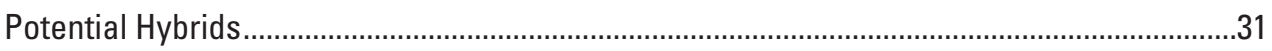

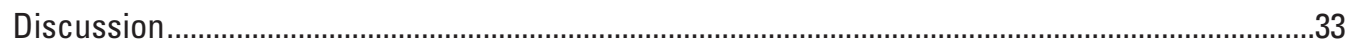

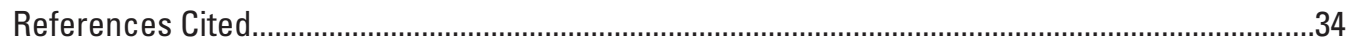

Appendix B1. Supplemental Principal Component Analysis Plot................................................36

Appendix B2. Snapclust Hybrid Test Results ................................................................................ 
Appendix B3. Maximum Likelihood Tree 37

Appendix B4. Discriminate Analysis of Principal Components Results... 38

\section{Figures}

A1. Site map showing all locations surveyed for howellii in May and June 2019.

A2. Photographs showing representative site images from surveyed locations where howellii was found

A3. Graph showing individual howellii observed outside of the constructed dune restoration within Antioch Dunes National Wildlife Refuge Stamm Management Area 1.

A4. Images showing count of howellii individuals within Antioch Dunes National Wildlife Refuge Stamm and Sardis Units.

A5. Images showing density of howellii individuals at surveyed sites across the region....10

A6. Graph showing how the decreasing total plant cover increased total adult howellii present across all sites..

A7. Graph showing how increased plant cover decreases the ratio of juvenile to adult howellii at field sites.

A8. Graph showing breakpoint analysis of the relationship between normalized difference vegetation index and adult howellii density ....

A9. Images showing continuous and categorized normalized difference vegetation index at Antioch Dunes National Wildlife Refuge Stamm Unit.

A10. Images showing categorized normalized difference vegetation index across all sites surveyed with a grid system......

A11. Images showing spatial coverage of historical interior dune habitat and entisols in the Antioch region

A12. Map showing areas identified as suitable habitat using normalized difference vegetation index within the historical Antioch sand sheet.

A13. Map showing areas identified as suitable habitat using normalized difference vegetation index within the historical Antioch sand sheet with all classes of developed land cover removed.

A14. Pie chart showing percentage of areas identified as suitable habitat using normalized difference vegetation index within the historical Antioch sand sheet classified by land cover category

A15. Graph showing total acres needed to sustain 2 populations of 1,500 and 5 populations of 4,800 adult howellii individuals over ranges of total plant community cover

B1. Photographs showing variation in plant growth form and flower and sepal characteristics of the two described 0 . deltoides subspecies and the unknown clade included in this study

B2. Map showing locations sampled for genomic analysis in May and June 2019.

B3. Graph showing principal component analysis where each point represents an individual, each ellipse represents a sampling occurrence, and color indicates type

B4. Image showing FastSTRUCTURE barplot where color indicates identity to each of $\mathrm{K}=3$ genetic clusters, black lines separate sampled occurrences, and narrow bars represent individuals. 
B5. Diagram showing maximum likelihood tree collapsed at nodes with high bootstrap support.

B6. Discriminant analysis of principal components plot showing maximizing differences among genetic clusters.

\section{Tables}

A1. Existing and historical howellii populations and associated metadata .............................6

A2. Site summaries of howellii individual counts for all known populations from 2019 surveys

A3. Modeled acreage needed to reach an adult howellii population size of 1,500 and 4,800 individuals

B1. Occurrence summary table with type classification, location, sample size, and genetic diversity statistics

B2. Pairwise $\mathrm{F}_{\mathrm{ST}}$ estimates by population

\section{Conversion Factors}

U.S. customary units to International System of Units

\begin{tabular}{|c|c|c|}
\hline Multiply & By & To obtain \\
\hline \multicolumn{3}{|c|}{ Area } \\
\hline acre & 4,047 & square meter $\left(\mathrm{m}^{2}\right)$ \\
\hline acre & 0.4047 & hectare (ha) \\
\hline acre & 0.4047 & square hectometer $\left(\mathrm{hm}^{2}\right)$ \\
\hline acre & 0.004047 & square kilometer $\left(\mathrm{km}^{2}\right)$ \\
\hline
\end{tabular}

International System of Units to U.S. customary units

\begin{tabular}{lcl}
\hline \multicolumn{1}{c}{ Multiply } & \multicolumn{1}{c}{ By } & \multicolumn{1}{c}{ To obtain } \\
\hline centimeter $(\mathrm{cm})$ & 0.3937 & inch (in.) \\
meter $(\mathrm{m})$ & 3.281 & foot $(\mathrm{ft})$ \\
meter $(\mathrm{m})$ & 1.094 & yard $(\mathrm{yd})$ \\
\hline & Area & \\
\hline square meter $\left(\mathrm{m}^{2}\right)$ & 0.0002471 & acre \\
square kilometer $\left(\mathrm{km}^{2}\right)$ & 247.1 & acre \\
square meter $\left(\mathrm{m}^{2}\right)$ & 10.76 & square foot (ft $\left.{ }^{2}\right)$ \\
square kilometer $\left(\mathrm{km}^{2}\right)$ & 0.3861 & square mile (mi2) \\
\hline & Volume & \\
\hline microliter $(\mu \mathrm{L})$ & 0.000033814 & ounce, fluid (fl. oz) \\
\hline & Mass & \\
\hline nanogram $(\mathrm{ng})$ & $3.527 \times 10^{-11}$ & ounce, avoirdupois $(\mathrm{oz})$ \\
\hline
\end{tabular}




\section{Abbreviations}

$\begin{array}{ll}\text { ADNWR } & \text { Antioch Dunes National Wildlife Refuge } \\ \text { BDFWO } & \text { San Francisco Bay-Delta Fish and Wildlife } \\ \text { bp } & \text { base pair } \\ \text { CNDDB } & \text { California Natural Diversity Database } \\ \text { CNPS } & \text { California Native Plant Society } \\ \text { DA } & \text { discriminant axis } \\ \text { DAPC } & \text { discriminate analysis of principal components } \\ \text { ddRAD } & \text { double-digest restriction-site associated DNA sequencing } \\ \text { DNA } & \text { deoxyribonucleic acid } \\ \text { GPS } & \text { global positioning system } \\ \text { NDVI } & \text { normalized difference vegetation index } \\ \text { NWR } & \text { National Wildlife Refuge } \\ \text { PC } & \text { principal component } \\ \text { PCA } & \text { principal component analysis } \\ \text { PCR } & \text { polymerase chain reaction } \\ \text { RTK } & \text { Leica Real-Time Kinematic } \\ \text { SNP } & \text { single nucleotide polymorphism } \\ \text { SSURGO } & \text { soil survey geographic database } \\ \text { USFWS } & \text { U.S. Fish and Wildlife Service } \\ \text { USGS } & \text { U.S. Geological Survey } \\ \text { VCF } & \text { variant call format }\end{array}$




\title{
Distribution, Abundance, and Genomic Diversity of the Endangered Antioch Dunes Evening Primrose (Oenothera deltoides subsp. howellii) Surveyed in 2019
}

\author{
Edited by Karen M. Thorne and Amy G. Vandergast
}

\begin{abstract}
Sand dune ecosystems are highly dynamic landforms found along coastlines and riverine deltas where a supply of sand-sized material is available to be delivered by aquatic and wind environments. These unique ecosystems provide habitat for a variety of endemic and rare plant and animal species. Sand dunes have been affected by human development, sand mining, and shoreline stabilization from invasive weeds. This report provides a summary of a comprehensive literature review, field survey, and genomic analysis for the Antioch Dunes evening primrose (Oenothera deltoides subsp. howellii, hereafter howellii), an endemic species to the San Francisco Bay-Delta, California, which was listed as a federally endangered subspecies in 1978. Howellii is found on a historic dune sheet (the Antioch sand sheet) near the confluence of the Sacramento and San Joaquin Rivers. The Antioch sand sheet has been greatly altered by sand mining and land conversion into agriculture and urban development. In chapter A, we describe results of the literature review and field survey. We found howellii at eight locations with over 90 percent of the adult population and nearly 99 percent of juveniles observed on the Antioch Dunes National Wildlife
\end{abstract}

Refuge. We measured a negative relationship between howellii numbers and invasive weed cover, illustrating the importance of mobilized open sand for this species. In chapter B, we describe the genomic study results. We surveyed genomic diversity by using double-digest restriction-site associated sequencing to estimate population genetic structure and levels of diversity across all surveyed occurrences. The genomic analyses included outgroup samples of the closely related Oenothera deltoides subsp. cognata and three occurrences of an unknown taxon with intermediate morphology to cognata and howellii, which also occurs on the Antioch sand sheet, east of the Antioch Dunes National Wildlife Refuge. These three morphologically distinctive groups formed genetically distinctive clusters and well-supported monophyletic clades in clustering and phylogenetic analyses, respectively. There was no indication of recent hybridization among any of the groups. Among howellii occurrences, the Antioch Dunes National Wildlife Refuge contained the greatest genetic diversity. Our approach, which combined field surveys, habitat assessments, and genetic analyses, can provide useful information for the conservation and management of rare and at-risk plant species and highlights the uniqueness of the Antioch sand sheet floral diversity through the discovery of a putative new taxon within the bird-cage evening primrose species complex. 


\title{
Chapter A. Distribution and Abundance of the Endangered Antioch Dunes Evening-Primrose (Oenothera deltoides subsp. howellii)
}

\author{
By Scott F. Jones, Anna Kennedy, Chase M. Freeman, and Karen M. Thorne
}

\section{Acknowledgments}

This work was supported by the U.S. Fish and Wildlife Service Bay-Delta Fish and Wildlife Office, Friends of San Pablo Bay National Wildlife Refuge, Antioch Dunes National Wildlife Refuge, and the U.S. Geological Survey Western Ecological Research Center. For help with site logistics and general information, we would like to thank J. de la Cruz and J. McMurray from the city of Oakley; M. Ferrell from California Department of Water Resources; L. Terrazas, D. Brubaker, and S. Euing from the U.S. Fish and Wildlife Service Antioch Dunes National Wildlife Office; M. Moran and R. Pulizzi from Big Break Regional Shoreline; A. Janke from the city of Walnut Creek; B. O'Brien, T. Fitanides, and B. Anderson from the Regional Parks Botanic Garden; R. O'Dell from the Bureau of Land Management; D. Lake from East Bay California Native Plant Society; T. Barry and E. Dean from the University of California Davis Center for Plant Diversity Herbarium; the Contra Costa Water District; K. Heffernan and F. Takahashi from San Luis National Wildlife Refuge Complex; M. Hammond and C. Lare-Masters from East Bay Regional Park District; and V. Stewart from the San Francisco Botanical Garden.

\section{Executive Summary}

- The Antioch Dunes evening primrose (Oenothera deltoides subsp. howellii, hereafter howellii) was listed as a federally endangered subspecies in 1978. A comprehensive literature review was completed to determine the documented historical and current range of howellii and to identify characteristics of suitable habitat.

- Of the 16 sites identified from the literature, 8 were selected for field surveys: Antioch Dunes National Wildlife Refuge (Stamm and Sardis Units), Brannan Island, Browns Island, Dutch Slough, City of Oakley Parcel (Legless Lizard Preserve), Georgia-Pacific Corporation property, and Kemwater/Olin Corporation property.

- Howellii was present at all surveyed sites except Dutch Slough and Kemwater/Olin property. The majority of howellii are found on the Antioch Dunes National
Wildlife Refuge, with smaller populations persisting at Brannan Island, Browns Island, and the Regional Parks Botanic Garden, where outplantings were done in the 1970s. A naturally occurring population also exists on the City of Oakley Parcel.

- A total of 5,436 adult and 49,125 juvenile individuals were counted ( 96 percent of adults and nearly 100 percent of juveniles were found in the constructed dune restoration on the Stamm Unit in Management Area 1). Off-refuge populations contained only 1 percent of adults and 0.1 percent of juveniles.

- Decreasing total community plant cover was correlated with exponentially increasing howellii populations and altered howellii plant demography. Above 75-percent plant cover, which represents habitat invaded by non-native annual grasses, there were more adults than juveniles in a population, which may hamper long-term population viability.

- Sandy dune habitat, where large howellii populations exist, had a distinct $(<0.1)$ normalized difference vegetation index score, which could allow additional habitat to be identified by using satellite or aerial imagery and ancillary landscape variables.

\section{Introduction}

The Antioch Dunes National Wildlife Refuge (ADNWR) was established in 1980 to protect and provide critical habitat for three federally endangered species: Lange's metalmark butterfly (Apodemia mormo langei), Antioch Dunes evening primrose (Oenothera deltoides subsp. howellii, hereafter howellii), and Contra Costa wallflower (Erysimum capitatum var. angustatum; U.S. Fish and Wildlife Service, 1984). Although most of howellii exist at ADNWR, small populations were outplanted at Brannan Island, Browns Island, Point Reyes National Seashore, and the Regional Parks Botanic Garden (formerly Tilden Botanic Garden) in the 1970s in an effort to prevent the species' extinction (U.S. Fish and Wildlife Service, 2008).

The Antioch region contained an extensive sand dune system formed from the combination of wind-blown and riverine sedimentary processes acting over cycles of interglacial and glacial periods (Atwater, 1982; Powell, 1983). 
This dune system, the Antioch sand sheet, extended about 2 miles along the south bank of the San Joaquin River to the east of Antioch, and reached heights of 115 feet (U.S. Fish and Wildlife Service, 2002). Human alteration of the region, including conversion to dairy farms, vineyards, and a brick factory, dates back to the mid to late 1800s; in the 1900s, large scale sand mining and other industrial uses occurred (U.S. Fish and Wildlife Service, 2002). Sand mining and other impacts reduced dune heights to around 50 feet in elevation, at the highest. Today, most of the remaining dunes exist within the ADNWR boundary (U.S. Fish and Wildlife Service, 2002).

Howellii is a short-lived perennial that flowers between March and September and peaks in May (U.S. Fish and Wildlife Service, 2008). The modern distribution of howellii is on sandy soils associated with riverine dunes (U.S. Fish and Wildlife Service, 2008); the historical distribution on the broader Antioch sand sheet is unclear. Invasive, non-native vegetation encroachment into dune habitat is the leading threat to howellii, stabilizing dune systems, suppressing seedling recruitment, and limiting population growth (U.S. Fish and Wildlife Service, 2002; Thomson, 2005). Invasive vegetation also could inhibit germination of the substantial seedbank (Pavlik and others, 1993; Thomson, 2005). Removal of invasive vegetation from the substrate surrounding mature howellii individuals enhances seed germination rates and survival (Greene, 1995; Thomson, 2005). The impact of invasion may be substrate dependent, with insect herbivory affecting seedlings on dune sands and moisture or nutrient availability playing a role on clay soils (Pavlik and Manning, 1993).

\section{Goals and Objectives}

The U.S. Fish and Wildlife Service (USFWS) San Francisco Bay-Delta Fish and Wildlife Office (BDFWO) has completed or is in the process of developing recovery criteria, a species status assessment, and 5-year review for howellii. To inform these efforts, the overall goals of this chapter were to conduct a thorough survey of current and historical locations for the Antioch Dunes evening-primrose across the known range and explore the relationship of environmental variables to Antioch Dunes evening-primrose abundance and distribution. Specifically, we perform the following steps:

- Document the historical extent of howellii using a literature review,

- Quantify modern howellii population presence/absence and demography, and
- Determine habitat characteristics that indicate current and possible howellii population presence and demography.

\section{Methods}

\section{Literature Review}

A comprehensive literature review of peer-reviewed papers, news articles, vegetation databases, USFWS grey literature and internal documents, and herbaria collections was completed to document the historical and current range of howellii and to determine field survey sites. For web search engines, combinations of keywords "Antioch Dunes evening primrose," "Oenothera deltoides subsp. howellii," "Antioch Dunes," and "range" were used. Vegetation databases included CalFlora, USFWS Environmental Conservation Online System (ECOS), California Native Plant Society (CNPS) internal databases, and citizen-science platform iNaturalist. The USFWS provided a query of the California Department of Fish and Wildlife's California Natural Diversity Database (CNDDB).

We also searched herbaria databases that contain location information, including the Consortium of California Herbaria One ( $\mathrm{CCH} 1)$, The University and Jepson Herbaria of the University of California at Berkeley, and the BIO Herbarium at the University of Guelph (OAC-BIO Herbarium). An in-person visit was made to the UC Davis Center for Plant Diversity Herbarium to view specimens. The UC Davis Library Map Collection database was queried to look for any relevant soil or land use maps that might give an indication of where suitable habitat may have existed historically. The USFWS BDFWO provided documents including reports from past howellii surveys, summary spreadsheets of management actions, and CNDDB exports.

\section{Site Descriptions}

All study sites determined from the literature review are in the Bay-Delta region of California, near the confluence of the Sacramento and San Joaquin Rivers (fig. A1). Sites were historically part of a 6,700-acre dune sheet (McNally, 2014). Although soil dating work has shown multiple deposits of sand over time, most sand is thought to have been deposited during the most recent glaciation period (12,000-26,000 years ago; Atwater, 1982; Powell, 1983). Today, only remnants of this system remain because of climate and land use changes (Powell, 1983). 


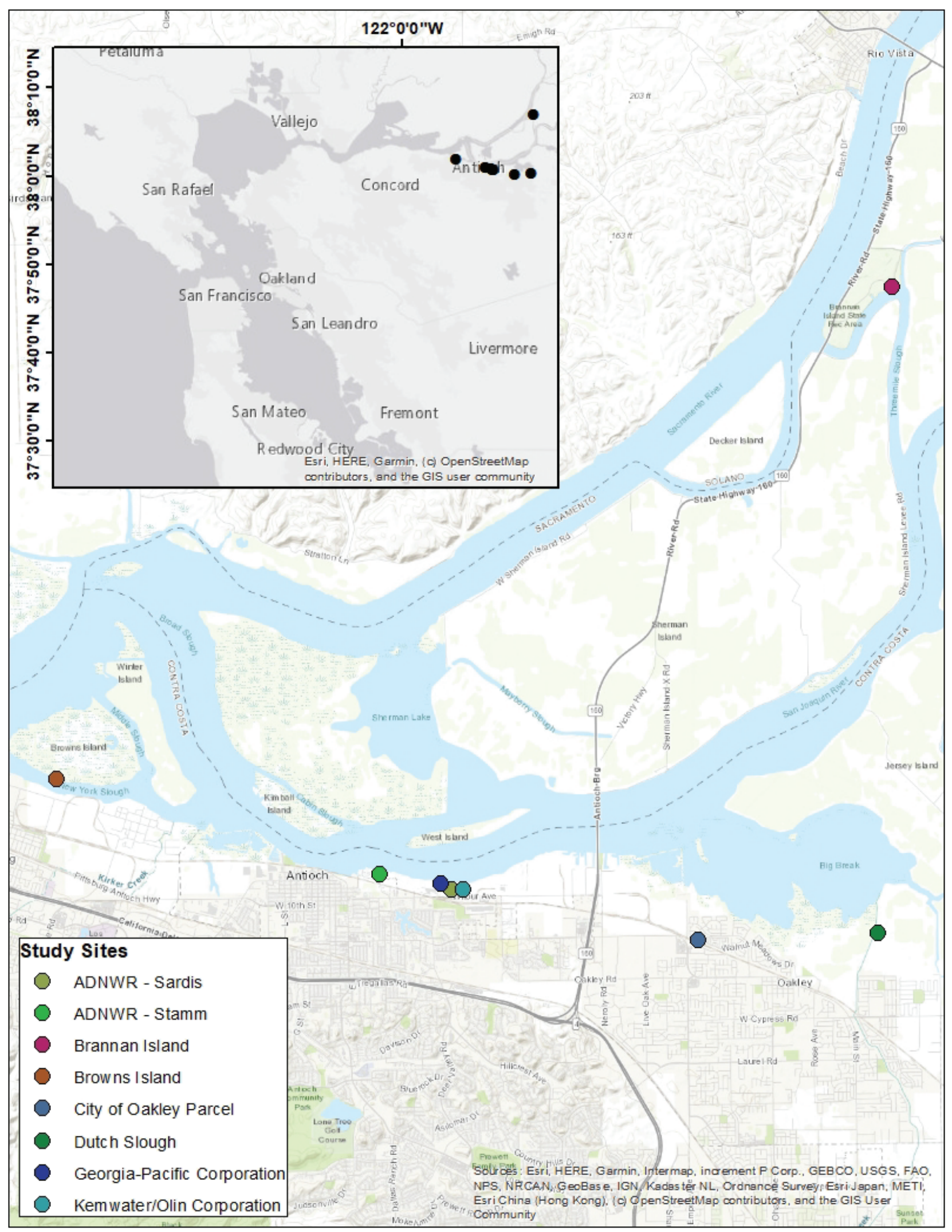

Map image is the intellectual property of Esri and is used herin under license. Copyright 2020 Esri and its licensors. All rights reserved.

Figure A1. Site map of all locations surveyed for howellii in May and June 2019. 
We visited eight sites where howellii was known or thought to be present (fig. A1): Antioch Dunes National Wildlife Refuge (ADNWR, Stamm and Sardis Units considered separately), Brannan Island State Recreation Area, Browns Island, City of Oakley Parcel (Legless Lizard Preserve), Dutch Slough vineyard, Georgia-Pacific Corporation property in Antioch, and Kemwater/Olin Corporation property in Antioch. Additionally, population estimates from the East Bay Regional Parks Botanic Garden in Berkeley were obtained. Within the ADNWR Stamm unit, a recent constructed dune restoration site (Stamm Management Area 1) was considered separately from the off-dune habitat within that unit. This constructed dune restoration consisted of open sand features constructed from the placement of sand dredge material onto ADNWR Stamm unit property.

\section{Howellii Distribution and Abundance}

Field surveys were done during peak bloom in May and June 2019 to determine the presence or absence of howellii and to count adult (buds, flowers, or fruit present) and juvenile (no sexual organs present) individuals. All sites were visited before surveying to determine if plants were present and the intensity of sampling necessary to count each individual. At sites where howellii populations were detected during site visits, field surveys were done using a grid system loaded on a Leica Real-Time Kinematic Global Positioning System (RTK GPS; \pm 1 centimeter $[\mathrm{cm}]$ horizontal, $\pm 2 \mathrm{~cm}$ vertical accuracy; Leica Geosystems Inc., Norcross, Georgia). At Brannan Island, Browns Island, and the City of Oakley Parcel, grid dimensions were 16 meters $(\mathrm{m})$ by $16 \mathrm{~m}$. At ADNWR, we used a pre-existing 20 - by 20 -m grid established during 2017 vegetation inventory surveys (Mathers and U.S. Fish and Wildlife Service, 2018). Surveyors walked transects through each grid counting the number of individuals, if present. A GPS point was taken at each individual plant to record location data and ensure that there was no double-counting. Where plants were clustered together (within 1 square meter $\left[\mathrm{m}^{2}\right]$ ), several individuals were recorded under one RTK point. On the constructed dune system, in the Stamm Management Area 1 of ADNWR RTK, surveys were not practical because of the high density of plants; RTK points were therefore only taken at individuals where leaves were collected for genetic analysis. All other individuals on the constructed dune were counted at the grid scale. To accomplish counts at the grid scale, flags were laid out at the corners of each grid using RTK, and all individuals were estimated in groups of 10 s or, rarely, 100s.

Additionally, representative photographs were taken of howellii at all sites where plants were located. These individual photographs were taken to document any morphological differences between howellii populations and as a record of occurrence. All count data were summarized as total populations within sites, and density of adult and juveniles (number of individuals in a grid/total grid area) to allow comparison between ADNWR and other sites. The ratio of juvenile to adult individuals was calculated for each grid by dividing the density of juveniles by the density of adults; ratios above 1 indicate higher density of juveniles than adults whereas ratios below 1 indicate higher density of adults than juveniles.

\section{Howellii Spatial Ecology}

For each sampling grid, a visual estimate of the total percent cover of the plant community was recorded. This estimate included all plants and is a proxy for how invaded the sandy substrate was by invasive annual grasses. Notes about the dominant plant community were recorded as well, and any specific features that could influence howellii (in other words, road or ant mound in grid) were recorded when present. The relationship between howellii density and total plant cover was quantified by using linear regression in R v3.6 (R Core Team, 2016); density was log-transformed to meet assumptions of homoscedasticity.

Soil type and normalized difference vegetation index (NDVI) were assessed to determine relationships to current howellii populations. In addition, these layers were used to locate potential habitat across the historical Antioch sand sheet. Historical land cover (Stanford and others, 2011) and soil type (Soil Survey Geographic Database [SSURGO], accessed in 2019, https://websoilsurvey.nrcs.usda.gov/) describe the historical spatial cover of the sand sheet. Modern land cover was then used to estimate remaining land that might support populations of howellii. The 2018 4-band National Agriculture Imagery Program (NAIP) imagery data layer was used to create the NDVI layer. Mean NDVI was calculated within each sampling grid in ArcGIS (Environmental Systems Research Institute [ESRI], 2011, ArcGIS Desktop: Release 10. Redlands, California) and extracted to the howellii grid data. The relationship between howellii density and NDVI was quantified using segmented regression in $\mathrm{R}$ to determine the NDVI breaks where howellii occurred.

\section{Results}

\section{Literature Review}

The literature review identified 16 sites to investigate as potential howellii populations. These sites historically contained howellii or were mentioned in internal USFWS documents, peer-reviewed literature, CNPS location records, or herbaria records (table A1). Of these sites, eight were visited to quantify total population size and demography of individuals (table A1). A summary of the literature review is provided in appendix A1. 
Table A1. Existing and historical howellii populations and associated metadata.

[USGS, U.S. Geological Survey; USFWS, U.S. Fish and Wildlife Service; NA, not applicable; CA, California; Dept, department; ADNWR, Antioch Dunes National Wildlife Refuge; $\sim$, approximately; $<$, less than]

\begin{tabular}{|c|c|c|c|c|c|c|}
\hline Site & Location & Ownership & Notes on occurrence & $\begin{array}{l}\text { Date of last } \\
\text { survey }\end{array}$ & $\begin{array}{l}\text { Population } \\
\text { size at last } \\
\text { survey }\end{array}$ & USGS action \\
\hline $\begin{array}{l}\text { Antioch Dunes } \\
\text { National Wildlife } \\
\text { Refuge (Sardis } \\
\text { Unit and Stamm } \\
\text { Management } \\
\text { Areas 2-4) }\end{array}$ & $\begin{array}{l}38.015904 \\
-121.795575\end{array}$ & USFWS & $\begin{array}{l}\text { Naturally occurring } \\
\text { population }{ }^{1} \text {. }\end{array}$ & 2017 & 102,334 & Resurvey site \\
\hline $\begin{array}{l}\text { Antioch Dunes } \\
\text { National Wildlife } \\
\text { Refuge - Stamm } \\
\text { Management } \\
\text { Area 1 }\end{array}$ & $\begin{array}{l}38.016492 \\
-121.799392\end{array}$ & USFWS & $\begin{array}{l}\text { Naturally occurring } \\
\text { population }{ }^{1}\end{array}$ & 2018 & 132,930 & Resurvey site \\
\hline Browns Island & $\begin{array}{l}38.033497 \\
-121.869026\end{array}$ & $\begin{array}{l}\text { East Bay Regional } \\
\text { Parks District } \\
\text { (EBRPD) }\end{array}$ & $\begin{array}{l}\text { Outplanting from } \\
\text { ADNWR in } 1978 . \\
\text { EBRPD provided } \\
\text { location data. }{ }^{1}\end{array}$ & 2018 & 134 & Resurvey site \\
\hline $\begin{array}{l}\text { City of Antioch } \\
\text { Vacant Lot }\end{array}$ & $\begin{array}{l}38.012952 \\
\quad-121.766900\end{array}$ & City of Antioch & $\begin{array}{l}\text { Under eucalyptus east } \\
\text { end of property. } \\
\text { Currently vehicle lot. }\end{array}$ & 1992 & 424 & $\begin{array}{l}\text { No further } \\
\text { action }\end{array}$ \\
\hline $\begin{array}{l}\text { City of Oakley } \\
\text { Parcel }\end{array}$ & $\begin{array}{l}38.003748 \\
-121.729023\end{array}$ & City of Oakley & $\begin{array}{l}\text { Presumed to be naturally } \\
\text { occurring population. }\end{array}$ & 1998 & 430 & Resurvey site \\
\hline $\begin{array}{l}\text { Kemwater/Olin } \\
\text { Corporation }\end{array}$ & $\begin{array}{l}38.013603 \\
-121.780598\end{array}$ & Private property & $\begin{array}{l}\text { On/down slope abutting } \\
\text { USFWS Sardis Unit }{ }^{10} \text {. }\end{array}$ & 2007 & $1<50$ & Resurvey site \\
\hline $\begin{array}{l}\text { Lime Ridge Open } \\
\text { Space }\end{array}$ & $\begin{array}{l}37.945896, \\
\quad-121.989560 \\
\text { (estimated) }\end{array}$ & $\begin{array}{l}\text { City of Walnut } \\
\text { Creek }\end{array}$ & $\begin{array}{l}\text { Howellii and cognata } \\
\text { reportedly observed by } \\
\text { B. Pavlik }{ }^{6} \text {. Abandoned } \\
\text { sand quarry contained } \\
\text { potential hybrids }{ }^{7.8} \text {. } \\
\text { Site developed } 9 \text {. }\end{array}$ & Late $1990 \mathrm{~s}$ & Unknown & $\begin{array}{l}\text { No further } \\
\text { action }\end{array}$ \\
\hline $\begin{array}{l}\text { Point Reyes } \\
\text { National Seashore }\end{array}$ & Unknown & $\begin{array}{l}\text { U.S. National Park } \\
\text { Service }\end{array}$ & $\begin{array}{l}\text { Outplanting done in } \\
1970 \text { s_-failed }{ }^{1} \text {. }\end{array}$ & Unknown & 0 & $\begin{array}{l}\text { No further } \\
\text { action }\end{array}$ \\
\hline $\begin{array}{l}\text { Private property in } \\
\text { Oakley }\end{array}$ & Unknown & Private property & $\begin{array}{l}\text { Specific location } \\
\text { undeterminable } 4 . \\
\text { Presumed }\end{array}$ & 1978 & 41 & $\begin{array}{l}\text { No further } \\
\text { action }\end{array}$ \\
\hline $\begin{array}{r}\text { Rancho Santa Ana } \\
\text { Botanic Garden }\end{array}$ & $\begin{array}{l}34.110550 \\
\quad-117.714771\end{array}$ & $\begin{array}{c}\text { Rancho Santa Ana } \\
\text { Botanic Garden }\end{array}$ & $\begin{array}{l}\text { Cultivated in botanic } \\
\text { garden } 9 .\end{array}$ & 2014 & 92 & $\begin{array}{l}\text { No further } \\
\text { action }\end{array}$ \\
\hline
\end{tabular}


Table A1. Existing and historical howellii populations and associated metadata.-Continued

[USGS, U.S. Geological Survey; USFWS, U.S. Fish and Wildlife Service; NA, not applicable; CA, California; Dept, department; ADNWR, Antioch Dunes National Wildlife Refuge; $\sim$, approximately; $<$, less than]

\begin{tabular}{|c|c|c|c|c|c|c|}
\hline Site & Location & Ownership & Notes on occurrence & $\begin{array}{c}\text { Date of last } \\
\text { survey }\end{array}$ & $\begin{array}{l}\text { Population } \\
\text { size at last } \\
\text { survey }\end{array}$ & USGS action \\
\hline $\begin{array}{l}\text { Regional Parks } \\
\text { Botanic Garden }\end{array}$ & $\begin{array}{l}37.892893 \\
-122.242802\end{array}$ & $\begin{array}{c}\text { East Bay Regional } \\
\text { Parks District }\end{array}$ & $\begin{array}{l}\text { 1Outplanting done in } \\
1970 .\end{array}$ & 2014 & 921 & $\begin{array}{r}\text { Population } \\
\text { estimate }\end{array}$ \\
\hline $\begin{array}{l}\text { San Francisco } \\
\text { Botanical Garden } \\
\text { at Strybing } \\
\text { Arboretum }\end{array}$ & $\begin{array}{l}37.767724 \\
-122.469312\end{array}$ & $\begin{array}{l}\text { San Francisco } \\
\text { Botanical } \\
\text { Garden }\end{array}$ & $\begin{array}{l}\text { Cultivated in botanic } \\
\text { garden. No plants in } \\
\text { collection at present }{ }^{15} \text {. }\end{array}$ & 2014 & 153 & $\begin{array}{l}\text { No further } \\
\text { action }\end{array}$ \\
\hline
\end{tabular}

1U.S. Fish and Wildlife Service, 2008.

2U.S. Fish and Wildlife Service, 1984.

${ }^{3}$ M. Hammond, East Bay Regional Parks District, personal communication, 2019.

4East Bay chapter of the California Native Plant Society, 2019.

${ }^{5}$ Cain and others, 2004.

${ }^{6}$ Wong and Kolar, 2002.

${ }^{7}$ California Department of Fish and Wildlife, 2018.

8A. Janke, Walnut Creek Open Space, personal communication, 2019.

\section{Howellii Distribution and Abundance}

We confirmed the presence of howellii at six of the eight sites we visited (figs. A2-5; table A2). In addition, Regional Parks Botanic Garden provided individual counts. A total of 54,216 plants were counted, 5,220 of which were adults (table A2). More than 98 percent of individual howellii were found within ADNWR, with the constructed dune restoration at Stamm Management Area 1 accounting for 96 percent of adult individuals and nearly 100 percent of juvenile individuals at the time of surveying. A shapefile of individual GPS points for ADNWR Sardis Unit, ADNWR Stamm Unit outside of the constructed dune in Management Area 1, Brannan Island, Browns Island, Georgia-Pacific Corporation, and the City of Oakley Parcel are available as appendix A2.

\section{Howellii Spatial Ecology}

Populations across sites were not randomly distributed; decreasing total plant cover increased total howellii population numbers exponentially across all sites (fig. A6). Increased plant cover within a grid shifted populations toward adult plants with limited juveniles (fig. A7). Grids with more than 75-percent cover on average had fewer juveniles than adults and, therefore, could not replace themselves over time (fig. A7).
9 Center for Plant Conservation, 2014.

10U.S. Fish and Wildlife Service, 2019.

11California Consortium of Herbaria, 2019.

12Ontario Agricultural College BIO Herbatium, 2019.

13U.S. Fish and Wildlife Service, 2018.

14U.S. Fish and Wildlife Service, 2017.

${ }^{15 V}$. Stewart, San Francisco Botanical Garden, personal communication, 2019.

Given the strong relationship between total plant cover and number of howellii individuals, we modeled the acreage that would be necessary to reach adult howellii population sizes that match USFWS recovery criteria (draft at time of analysis, now finalized; U.S. Fish and Wildlife Service, 2019): 1,500 or 4,800 (table A3). 25-percent cover closely represents dune habitat, while 75-percent cover most closely represents an invaded annual grass habitat. A habitat at 90-percent cover is highly invaded. To support the same population of 4,800 individuals, a highly invaded habitat would require an order of magnitude more acreage (181-327 acres) than a dune habitat (13-22 acres; table A3).

High density howellii populations were found within a distinct range of NDVI values. In grids with NDVI less than 0.1 , there was a relationship between NDVI and howellii adult plant density; with high NDVI (indicating high plant cover); however, there was no relationship to adult plant density and few plants were found (fig. A8). Additionally, NDVI spatial patterns mirrored those found with total plant community cover and high howellii plant densities (fig. A9). Low plant cover and sandy habitat, such as the constructed dune restoration site on ADNWR Stamm Unit, had low NDVI values indicating high habitat quality, whereas the more invaded sites had higher values, indicating poor habitat quality (figs. A9-10). 


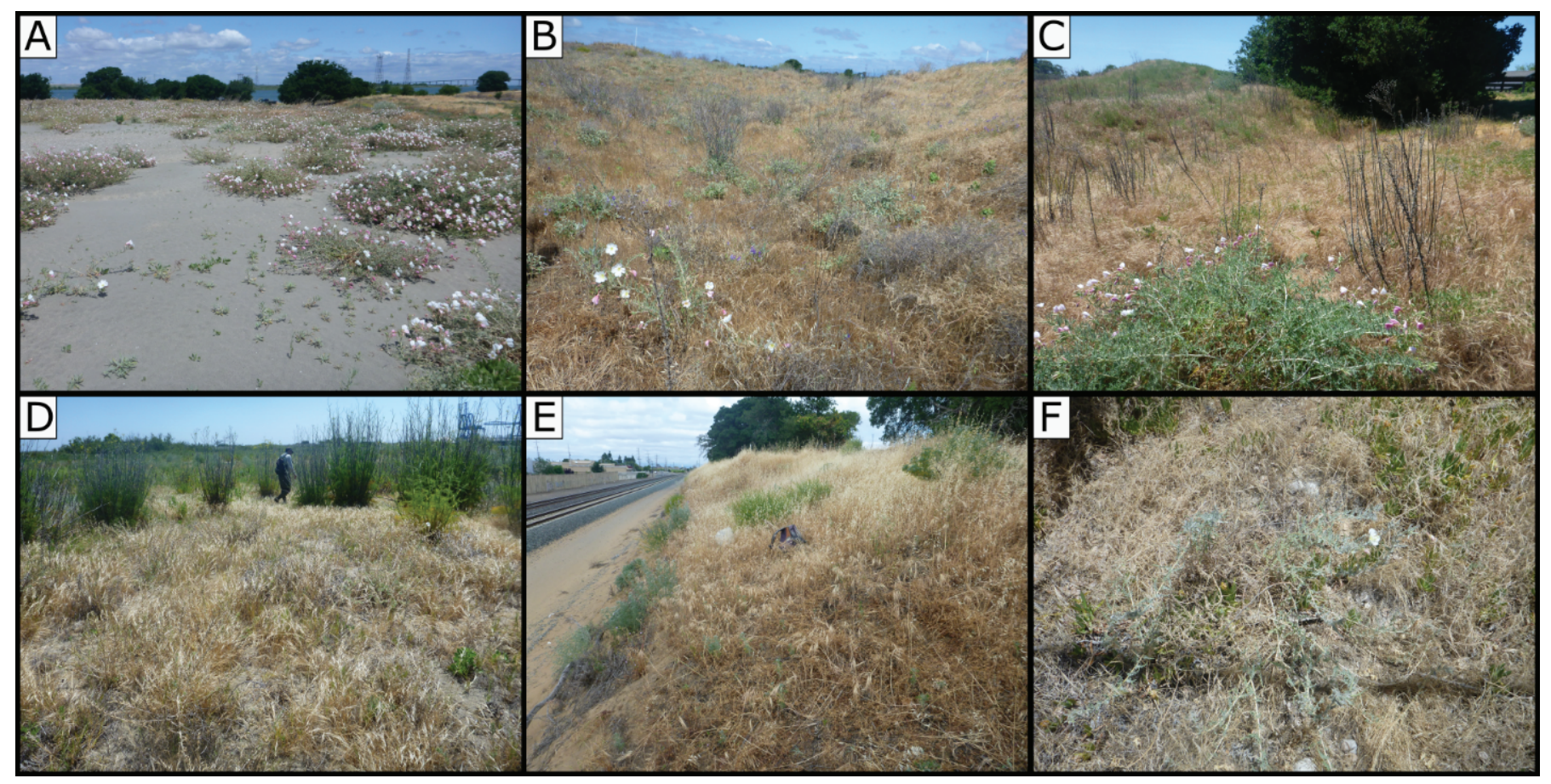

Figure A2. Representative site images from surveyed locations where howellii was found. $A$, Antioch Dunes National Wildlife Refuge (ADNWR) Stamm Management Area 1 on the constructed dune restoration; $B$, ADNWR Stamm Unit outside of Management Area 1 constructed dune (representative of Sardis Unit as well); C, Brannan Island; D, Browns Island; $E$, City of Oakley Parcel; and F, Georgia-Pacific Corporation. Photographs taken by Scott F. Jones, U.S. Geological Survey, May 2019.

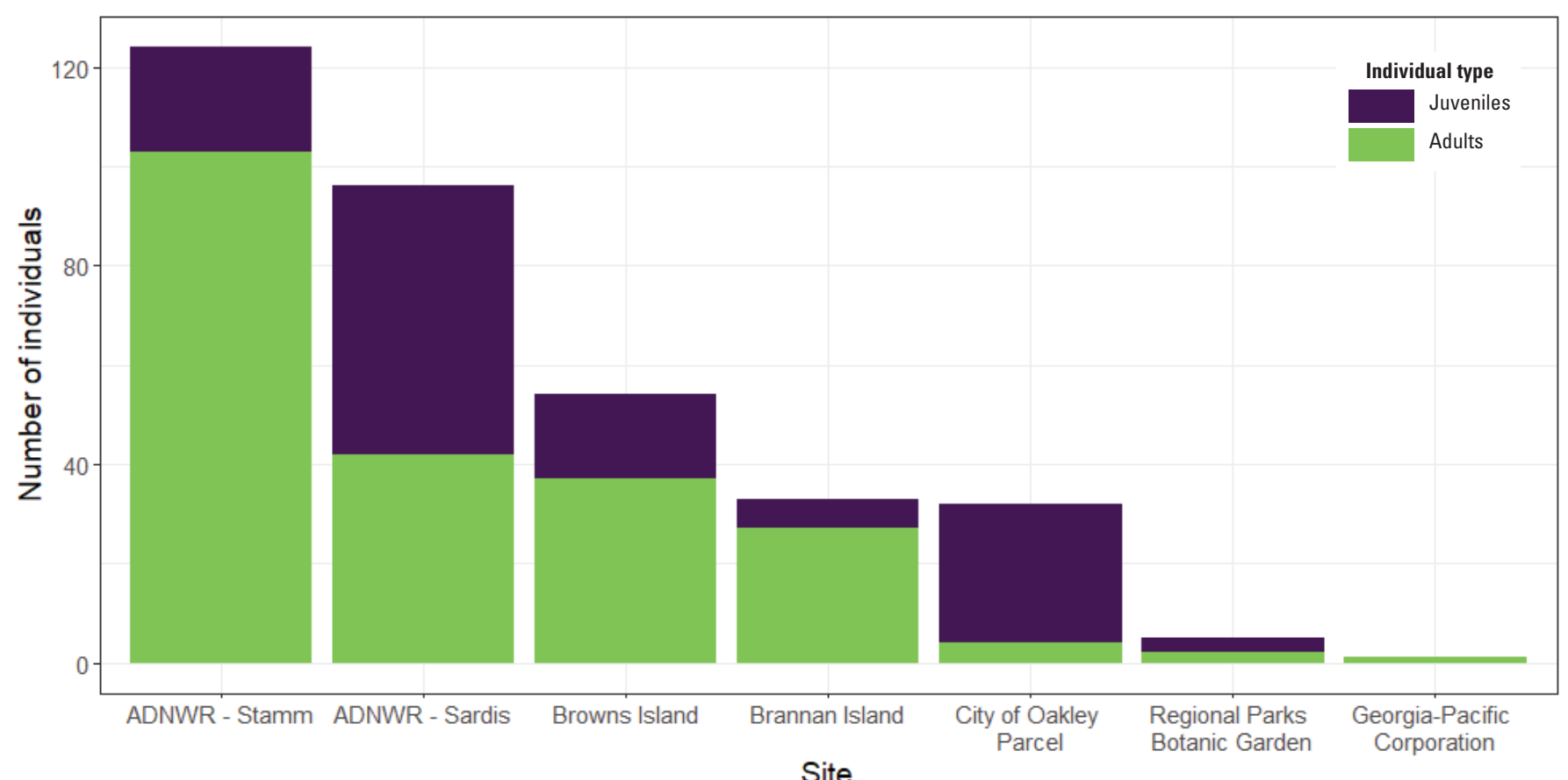

Figure A3. Individual howellii observed outside of the constructed dune restoration within Antioch Dunes National Wildlife Refuge (ADNWR) Stamm Management Area 1. 


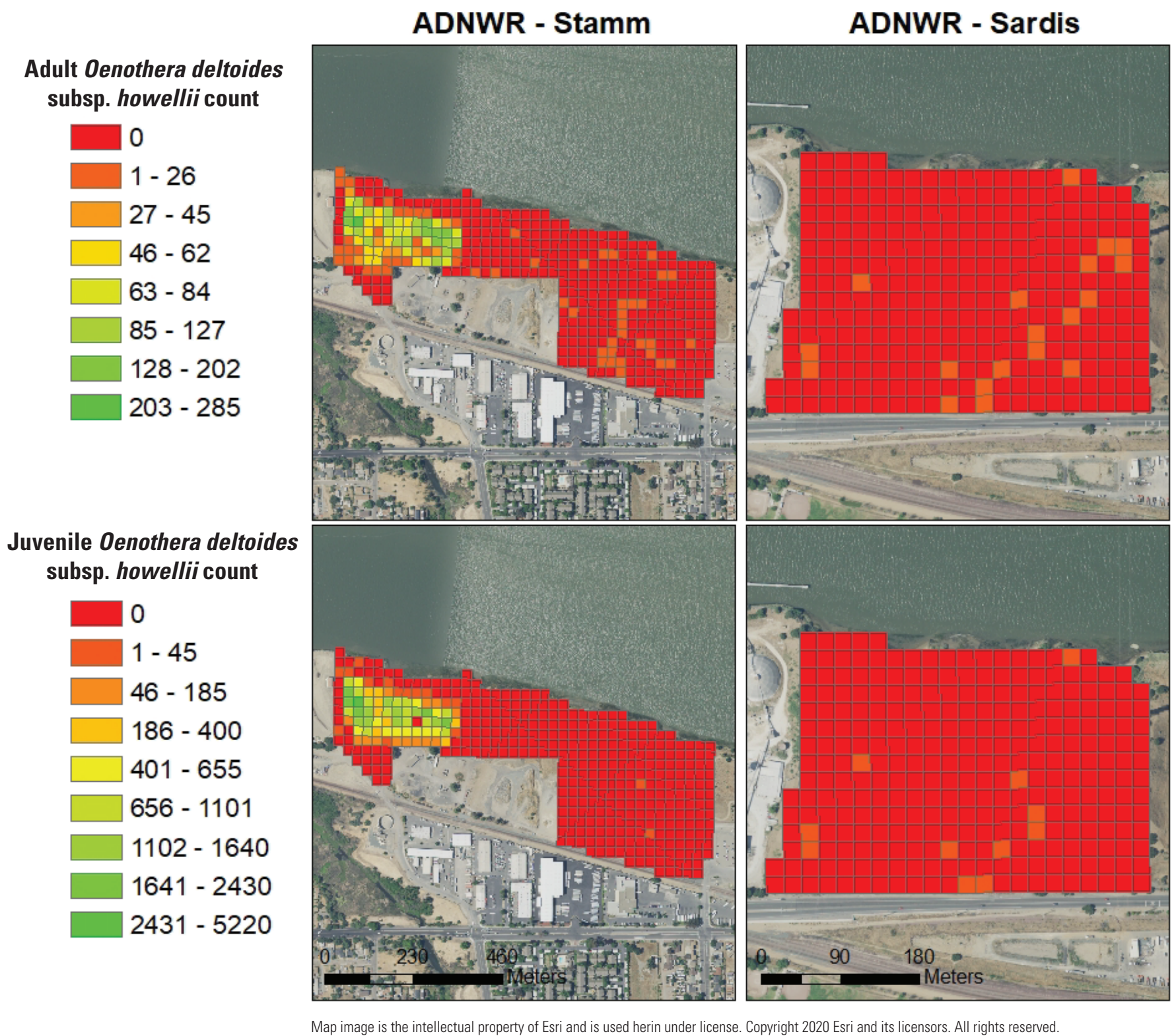

Figure A4. Count of howellii individuals within Antioch Dunes National Wildlife Refuge (ADNWR) Stamm and Sardis Units. 

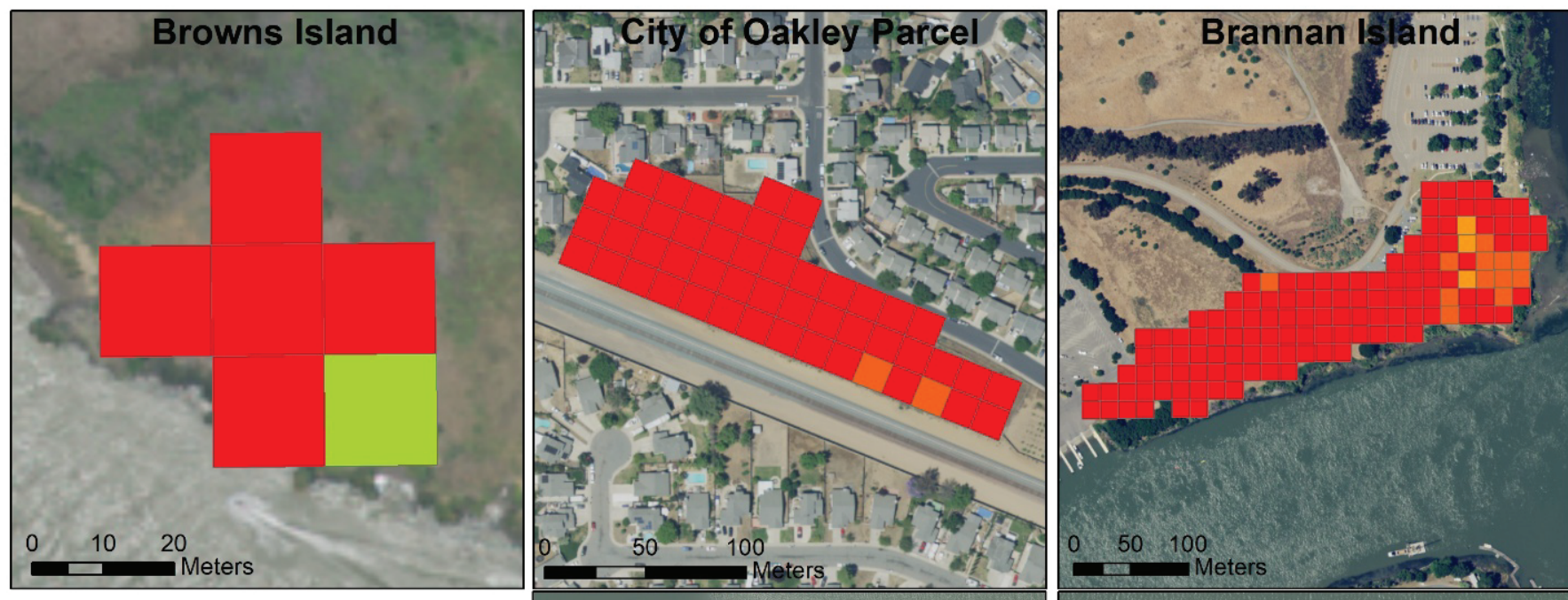

\section{Adult Oenothera deltoides subsp. howellii density,}

in count per acre

0.00

$0.01-40.51$

$40.52-121.54$

$121.55-263.32$

$263.33-577.29$

$577.30-850.74$

850.75 - 1498.91

$1498.92-2886.45$


Map image is the intellectual property of Esri and is used herin under license. Copyright 2020 Esri and its licensors. All rights reserved.

Figure A5. Density of howellii individuals at surveyed sites across the region.

Table A2. Site summaries of howellii individual counts for all known populations from 2019 surveys.

[ADNWR, Antioch Dunes National Wildlife Refuge]

\begin{tabular}{lrrr}
\hline \multicolumn{1}{c}{ Site } & $\begin{array}{c}\text { Adult } \\
\text { individuals }\end{array}$ & $\begin{array}{c}\text { Juvenile } \\
\text { individuals }\end{array}$ & $\begin{array}{c}\text { Total } \\
\text { individuals }\end{array}$ \\
\hline ADNWR—-constructed dune within Stamm Management Area 1 & 5,220 & 48,996 & 54,216 \\
ADNWR—Stamm Unit excluding constructed dune within Management Area 1 & 103 & 21 & 124 \\
ADNWR—Sardis Unit & 42 & 54 & 96 \\
Browns Island & 37 & 17 & 54 \\
Brannan Island & 27 & 6 & 33 \\
City of Oakley Parcel & 4 & 28 & 32 \\
Regional Parks Botanic Garden & 2 & 3 & 5 \\
Georgia-Pacific Corporation & 1 & 0 & 1 \\
Dutch Slough & 0 & 0 & 0 \\
Kemwater/Olin Corporation & 0 & 0 & 0 \\
\hline
\end{tabular}




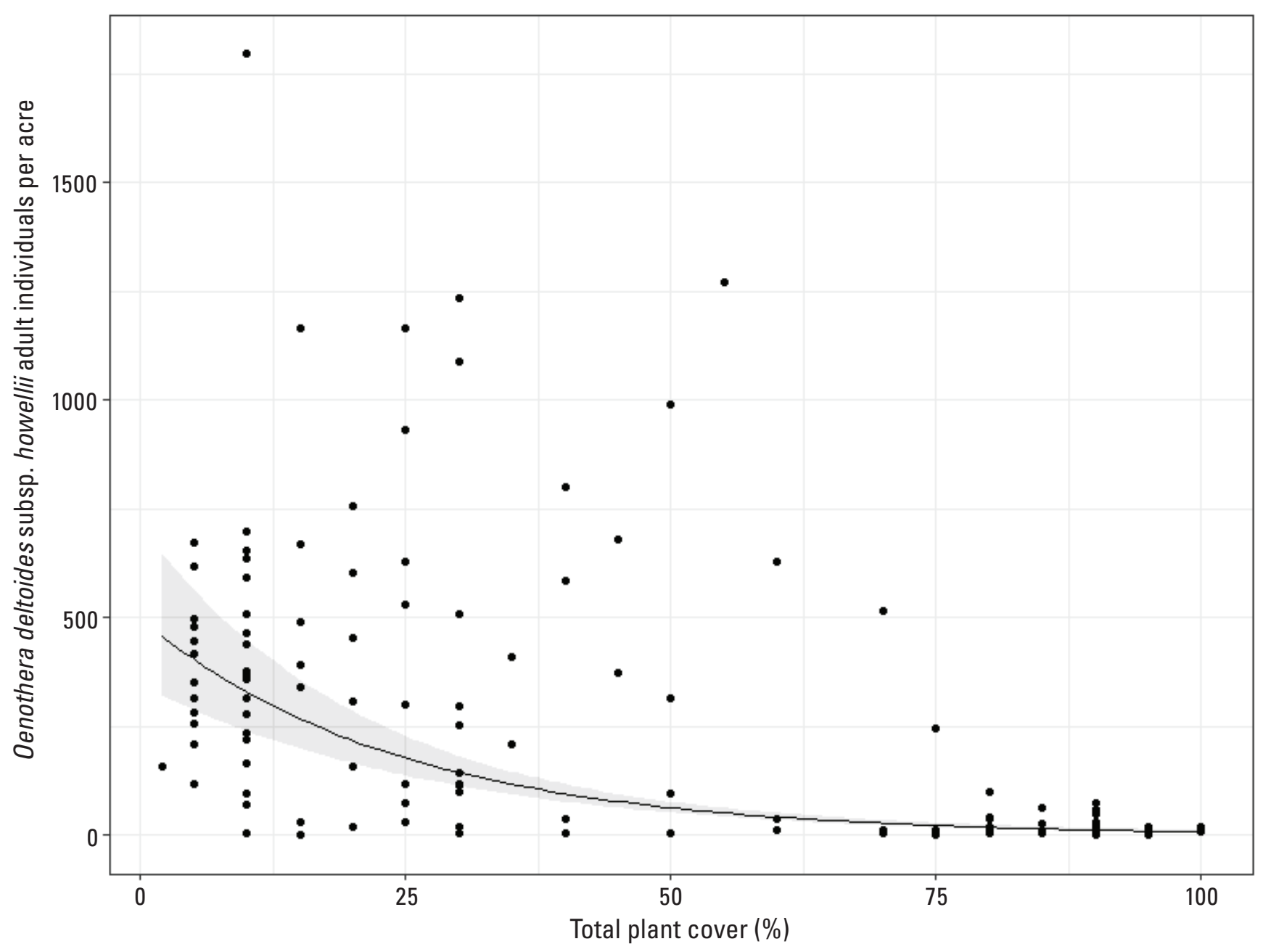

Figure A6. Based on field surveys, decreasing total plant cover increased total adult howellii present across all sites. Line is an exponential regression with shaded 95-percent confidence interval $\left(R^{2}=0.57, P<0.0001\right)$. Each point is a grid that contained howellii from our survey ( $n=154)$. 


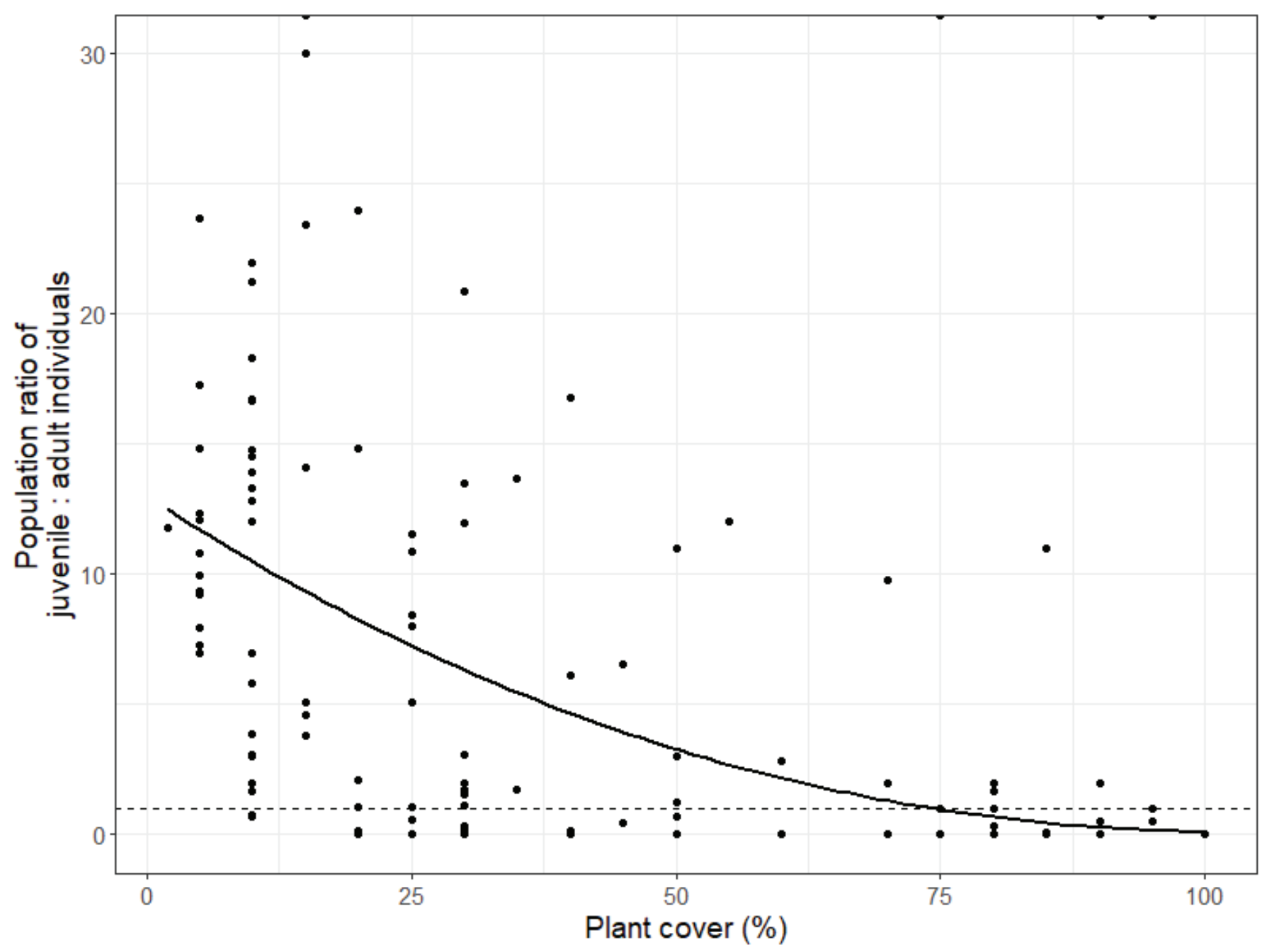

Figure A7. Based on field observations, increased plant cover decreases the ratio of juvenile to adult howellii at field sites. The dotted horizontal line at 1 represents a plant population that can replace itself with 0-percent mortality; populations below that line may not be sustainable. Each point is a grid that contained howellii from our surveys $(n=154)$. Total plant cover is the percent cover of the entire plant community.

Table A3. Modeled acreage needed to reach an adult howellii population size of 1,500 and 4,800 individuals.

[Total plant cover is the percent cover of the entire plant community. Acres presented as means with 95 -precent confidence intervals in parentheses.]

\begin{tabular}{ccc}
\hline $\begin{array}{c}\text { Total plant cover } \\
\text { (percentage) }\end{array}$ & $\begin{array}{c}\text { Acres needed for } \\
\text { population of 1,500 }\end{array}$ & $\begin{array}{c}\text { Acres needed for } \\
\text { population of 4,800 }\end{array}$ \\
\hline 5 & $2(2-3)$ & $7(5-10)$ \\
25 & $5(4-7)$ & $17(13-22)$ \\
50 & $15(12-18)$ & $47(39-57)$ \\
75 & $41(32-52)$ & $131(103-167)$ \\
90 & $76(57-102)$ & $243(181-327)$ \\
\hline
\end{tabular}




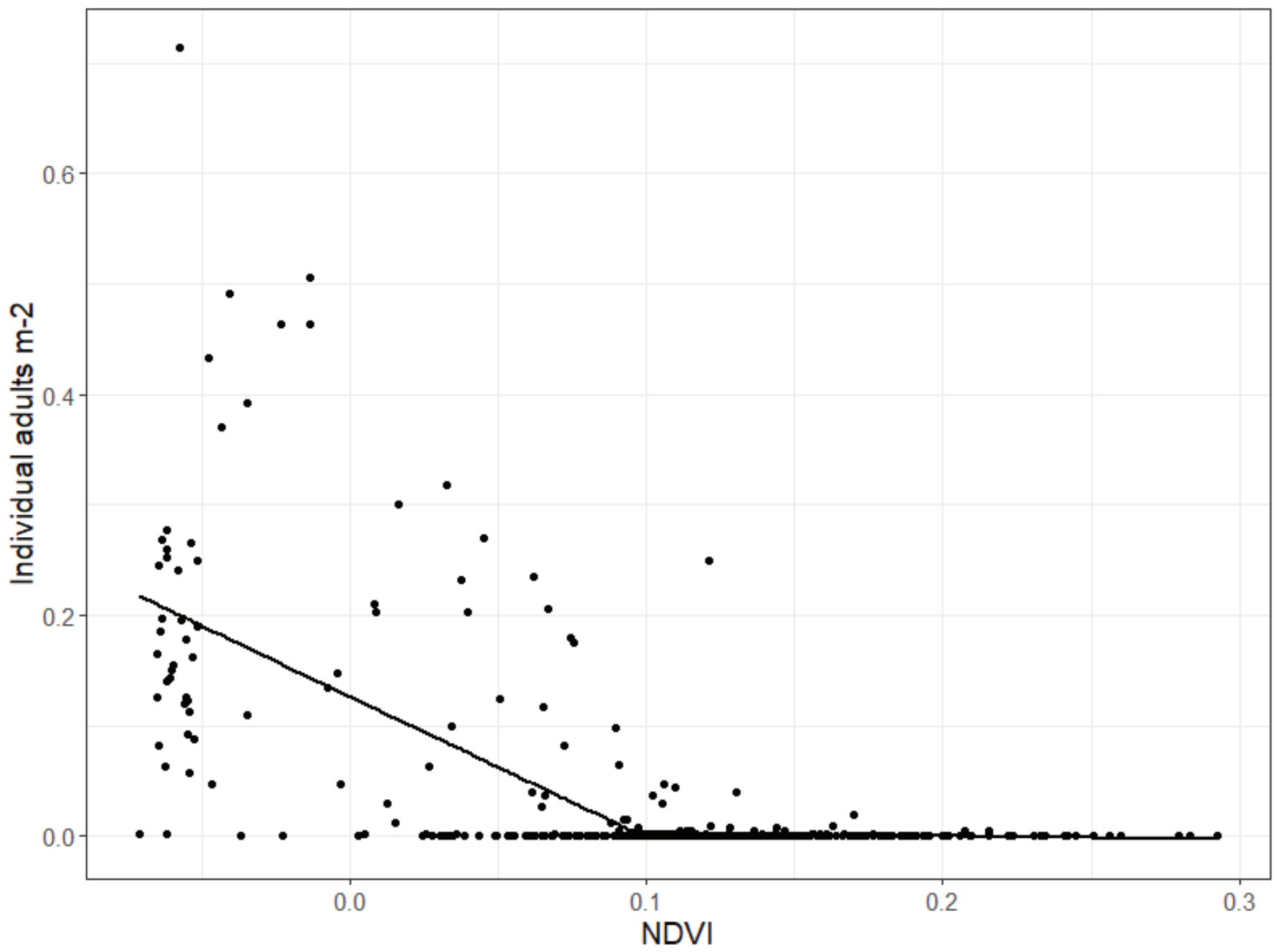

Figure A8. Breakpoint analysis of the relationship between normalized difference vegetation index (NDVI) and adult howellii density. Each point represents a grid where at least one plant was found $(n=154)$. Breakpoint=0.1. Line is segmented regression. 


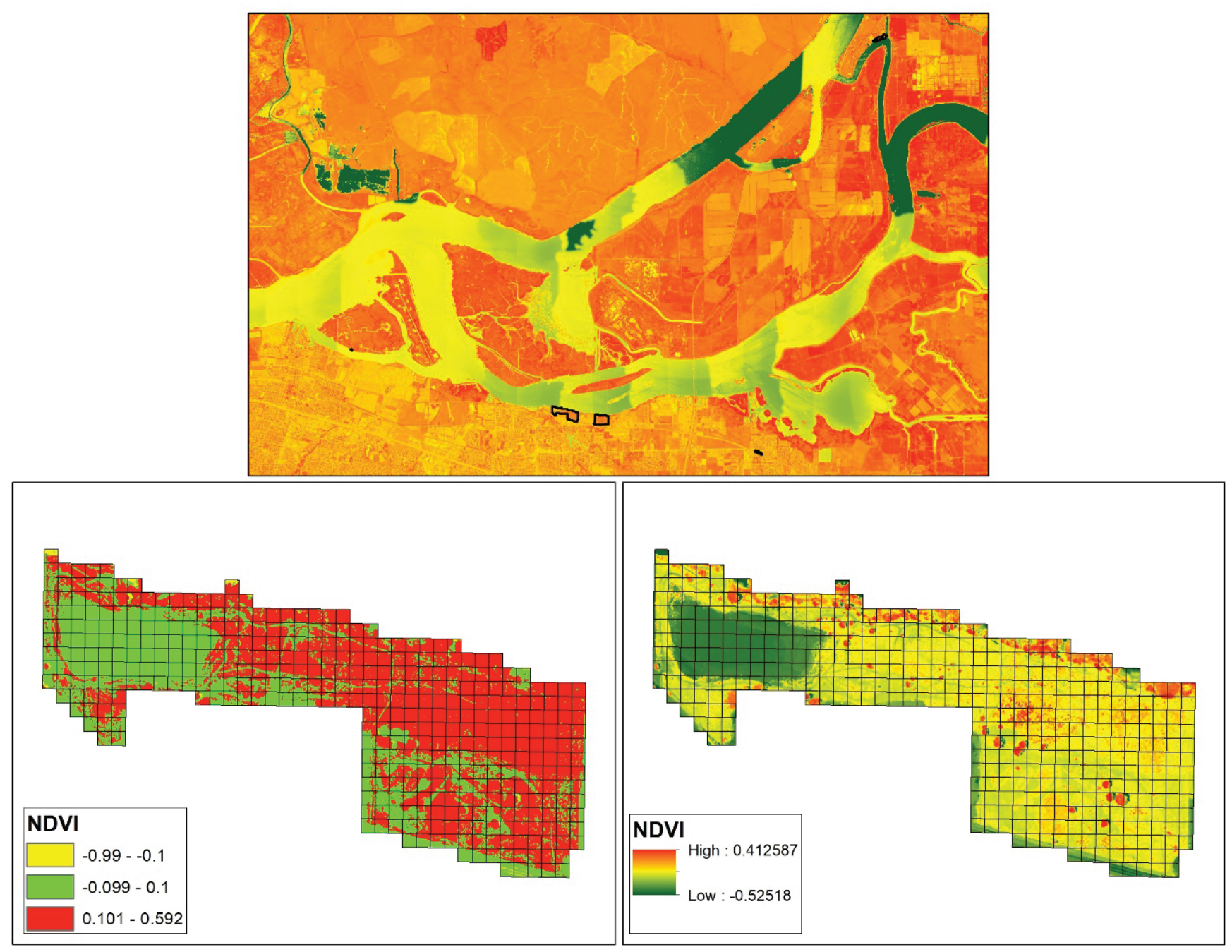

Figure A9. Continuous and categorized normalized difference vegetation index (NDVI) at Antioch Dunes National Wildlife Refuge Stamm Unit. Categorized NDVI (left) uses break from breakpoint analysis $(0.1)$ to highlight quality habitat in green. 

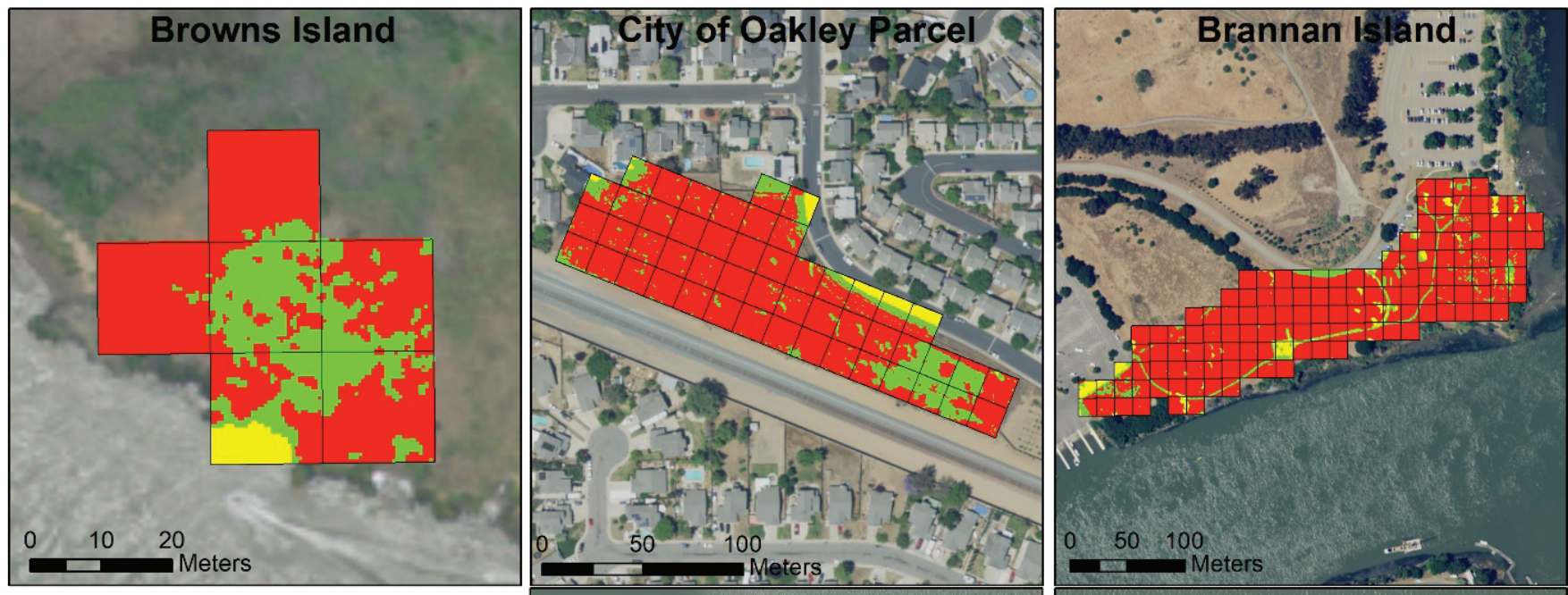

\section{ADNWR - Stamm}

\section{NDVI}
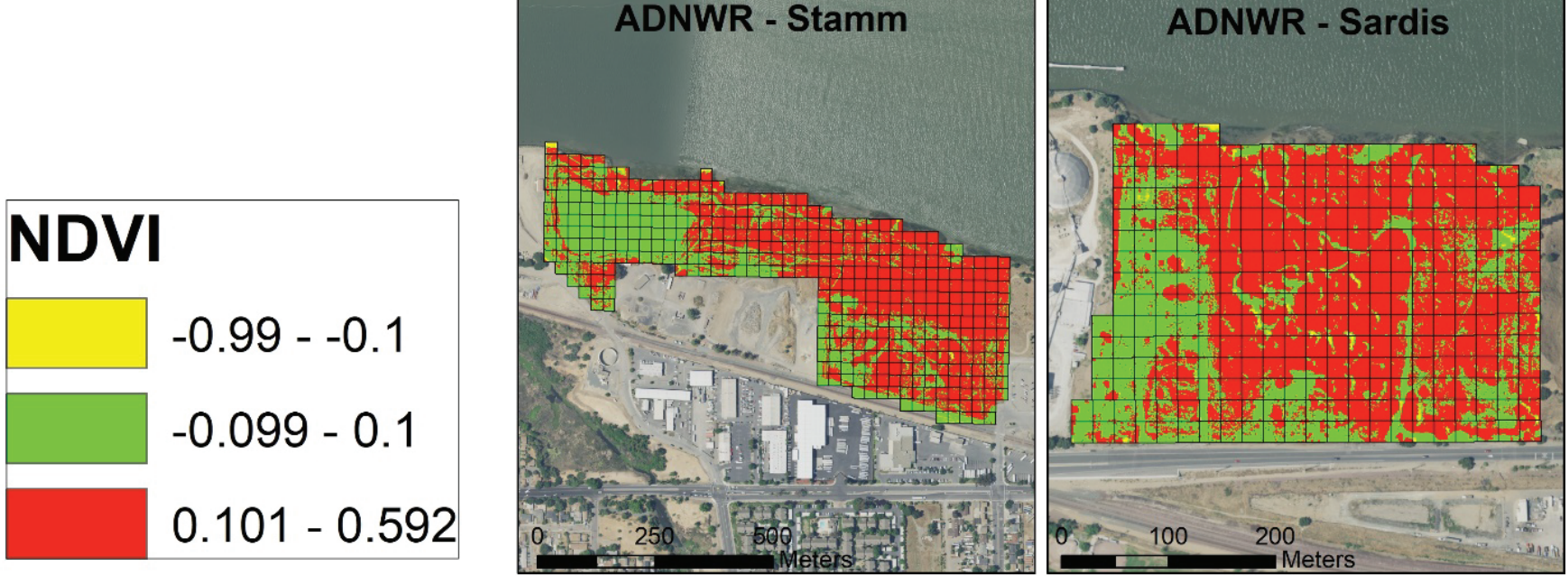

Map image is the intellectual property of Esri and is used herin under license. Copyright 2020 Esri and its licensors. All rights reserved.

Figure A10. Categorized normalized difference vegetation index (NDVI) across all sites surveyed with a grid system. Categories chosen by breakpoint analysis (break $=<0.1)$, to indic ate high quality habitat in green. Normalized difference vegetation index (NDVI) is a metric of greenness and plant density, where lower values typically represent low plant density.

Unconsolidated entisols (mineral soils that have not differentiated into distinct horizons) underlie the survey region where interior dune communities were common pre-development (fig. A11). Total acreage of the historical sand sheet was 34.4 square kilometers $\left(\mathrm{km}^{2}\right)$. Using 2018 imagery, the acreage of habitat within the historical sand sheet that has a modern NDVI within the range that supports howellii is $12.9 \mathrm{~km}^{2}$ (fig. A12). With developed land removed, there is a maximum of $5.6 \mathrm{~km}^{2}$ available that may support howellii, although this is an upper bound because it includes currently cultivated land (fig. A13). Normalized difference vegetation index values are likely to represent urban landforms and not quality dune habitat because most of the land within the NDVI range is developed (fig. A14). 


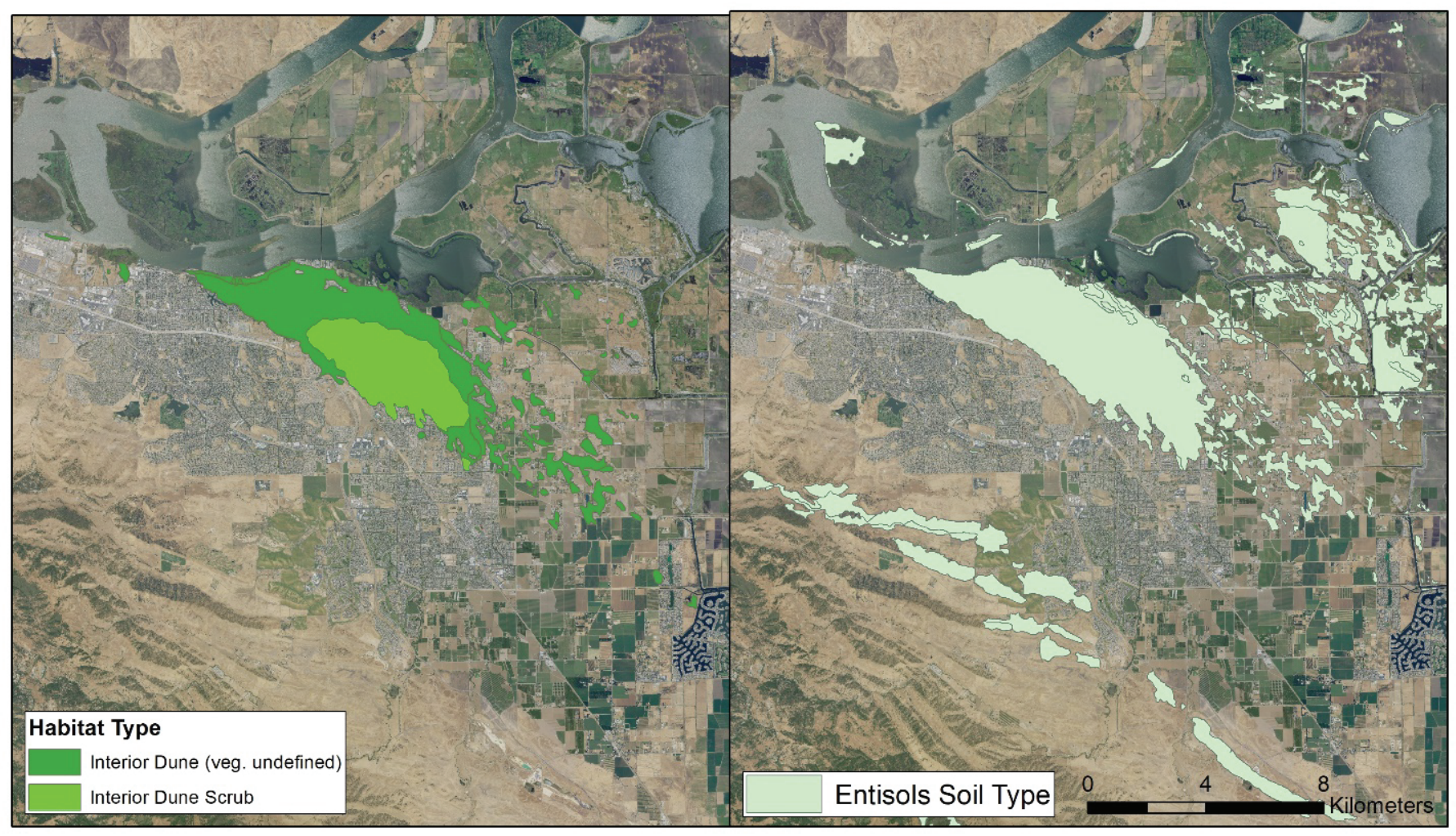

Map image is the intellectual property of Esri and is used herin under license. Copyright 2020 Esri and its licensors. All rights reserved.

Figure A11. Spatial coverage of historical interior dune habitat (left) and entisols (right) in the Antioch region. Habitat type data from Stanford and others (2011) and soil type data from Soil Survey Geographic Database (2019). 


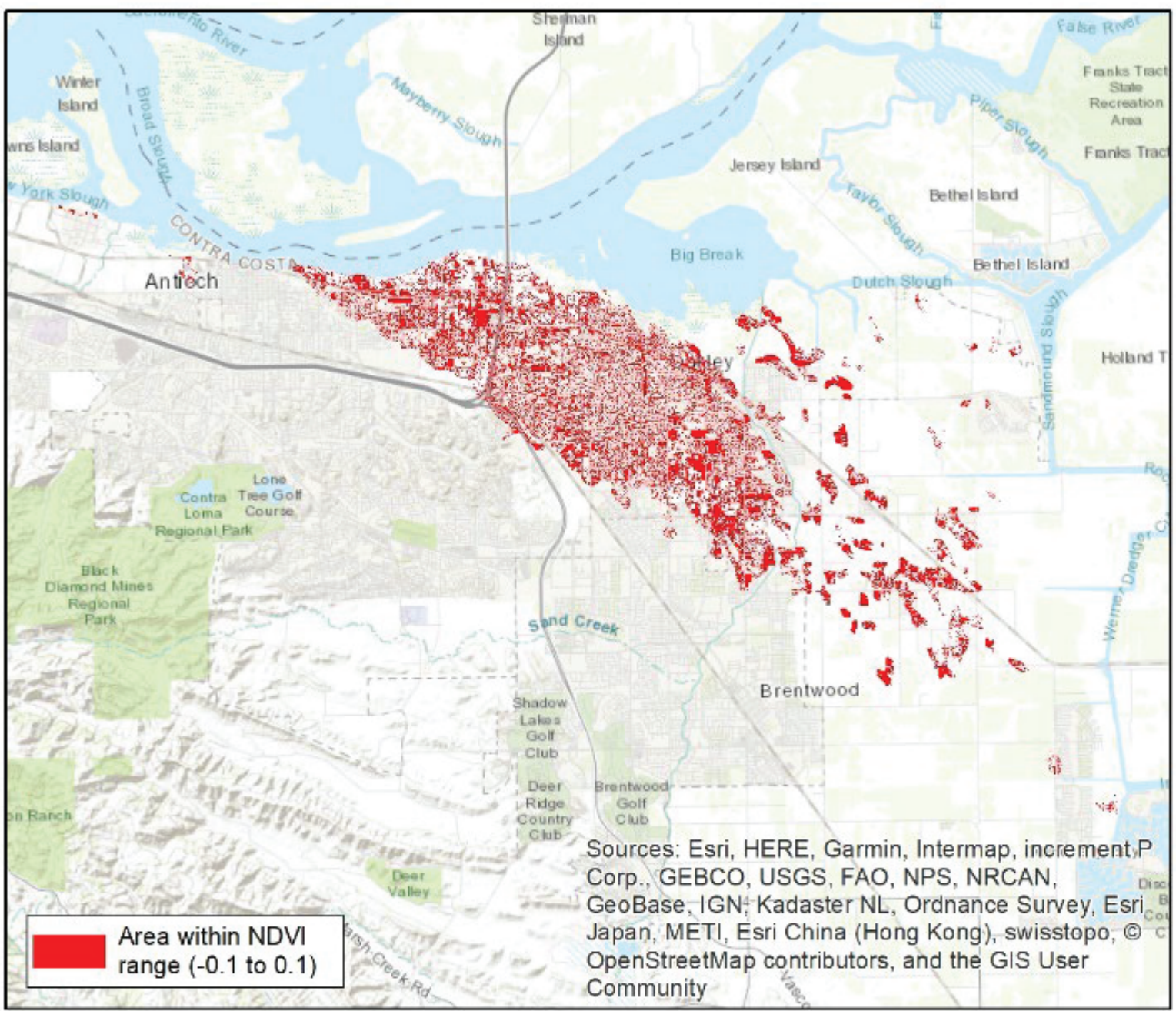

Map image is the intellectual property of Esri and is used herin under license. Copyright 2020 Esri and its licensors. All rights reserved.

Figure A12. Areas identified as suitable habitat using normalized difference vegetation index (NDVI) within the historical Antioch sand sheet. 


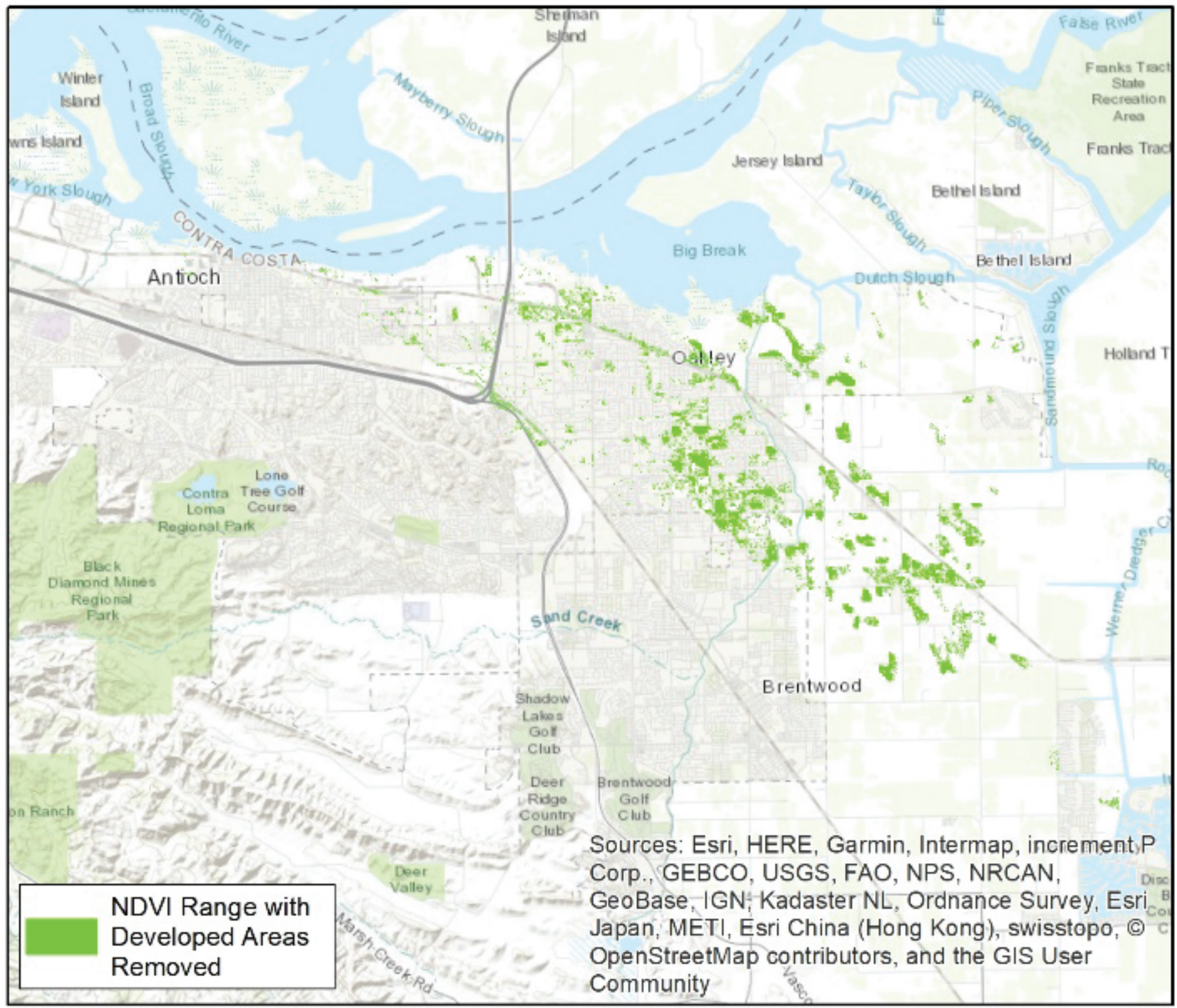

Map image is the intellectual property of Esri and is used herin under license. Copyright 2020 Esri and its licensors. All rights reserved.

Figure A13. Areas identified as suitable habitat using normalized difference vegetation index (NDVI) within the historical Antioch sand sheet with all classes (low, medium, high) of developed land cover removed 


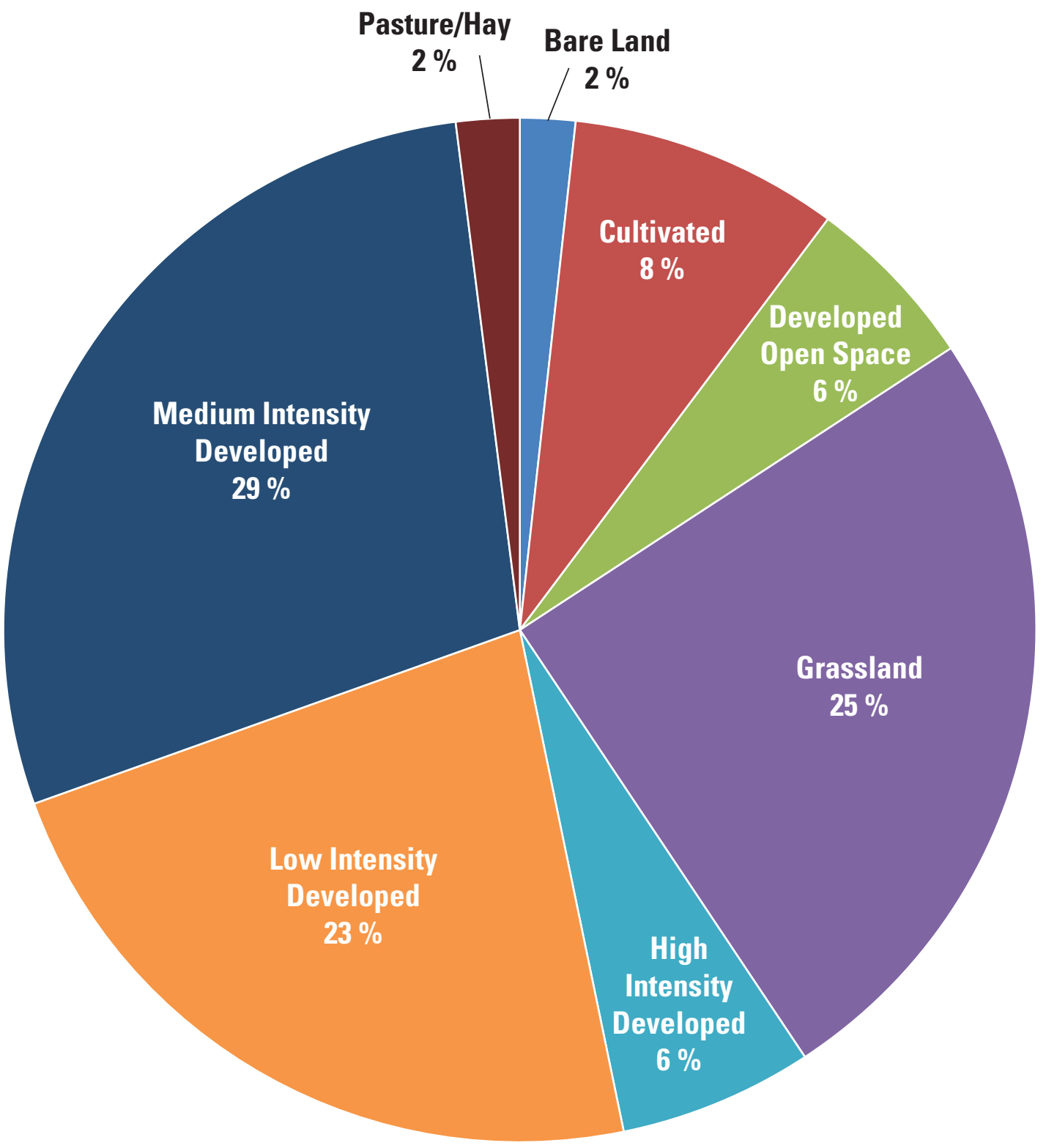

Figure A14. Percentage of areas identified as suitable habitat using normalized difference vegetation index within the historical Antioch sand sheet classified by land cover category. 


\section{Discussion}

\section{Dune Construction}

Our results indicated that habitat creation, such as that undertaken at the Stamm Management Area 1 of ADNWR, has the potential to increase howellii populations. We found the highest population densities on the constructed dune habitat and the highest juvenile to adult ratios. The dune is not dispersal-limited because thousands of individuals naturally recruited into the site within a year of restoration. The proximity to other protected habitat may underpin the lack of dispersal barriers; constructed sites located far from any source populations may not show the same success because of lack of pollinators or other constraints (Pavlik and others, 1993). When dredge spoil or other dune construction projects occur beyond the natural dispersal range of howellii, populations could still be viable if transplanted. The Brannan Island howellii population, for example, occurs on old dredge spoil from the 1920s (U.S. Fish and Wildlife Service, 2002; California Department of Parks and Recreation, 2019). Dune construction can be effective by providing open space with mobile sand while reducing competition from other species, which are key drivers of juvenile germination or establishment (Pavlik and Manning, 1993; Greene, 1995).

\section{Habitat Management}

We found strong relationships between total plant community cover and howellii population size and demography. Total plant cover therefore could be a quantifiable indicator of habitat quality for howellii and is relatively easy to measure in the field. Management of existing habitat to reduce total plant cover may increase howellii populations and shift demography toward juveniles. The difference in distribution and demography of juvenile howellii between areas with bare ground and those with high total plant cover supports previous findings that bare, sandy ground is important for juvenile success (Pavlik and Manning, 1993; Greene, 1995; Thomson, 2005). Populations in areas with low total plant cover had higher proportions of juveniles and therefore a better chance of growing or stable populations over time, compared to areas with high total plant cover made up mostly of adult plants. Because howellii is a short-lived perennial, recruitment is a key demographic transition for population growth and one that may be facilitated by low plant cover (Thomson, 2005).

The mechanisms underlying the impact of total plant cover on juvenile recruitment are unclear. It could be that light is necessary for successful germination or that invasive grasses and other vegetation compete strongly for water or nutrients to prevent successful establishment of seedlings (Pavlik and others, 1993; Greene, 1995). Disturbance of the soil also could be necessary for germination (Thomson, 2005) because dune stabilization by vegetation may reduce sand action that scarifies the seed coat to promote germination. Experimental seedbank germination studies are needed to test if howellii is present in invaded habitat but isn't germinating because of dune stabilization (for example, competition or reduced light). If present in invaded habitat seedbanks, restoration activities that reduce total plant cover could be successful in jumpstarting howellii populations. Additionally, field studies that test the effect of total plant cover on seedling establishment and recruitment, and greenhouse studies that test the effects of light, nutrients, and water availability separately are necessary to fully disentangle the mechanisms by which plant cover influences howellii population demography. These studies are especially crucial in locations where adult and juvenile plants are present and land management activities that reduce plant cover are feasible. One possibility is that detection of juveniles is lower in invaded habitats because of difficulty in locating individuals; explicit tests of surveyor detection error are needed to constrain this possibility.

\section{Potential Available Habitat}

The original extent of habitat that may have supported howellii or similar dune specialist species covered a broad range in the Antioch area. With the sand sheet area now under fast-paced development, the potential available habitat for dune specialists is much reduced and declining quickly. Our map of potential quality habitat gives a baseline search extent for further analysis that could potentially pinpoint habitat that can support howellii. Identifying NDVI values between -0.1 and 0.1 with low variation across time within this extent will allow further reduction of the focus area and direct attention on land parcels that may hold relict populations or could potentially support outplanting operations. The analyses presented here provide maximum potential habitat; future analyses will need to verify and constrain broad land cover classes to remove roads, levees, and other landforms not conducive to plant populations of concern.

\section{Considerations}

Regardless of whether habitat creation or habitat management is used, the total acreage necessary to sustain populations of adult howellii is greatly reduced when that habitat has low total plant cover. To sustain population sizes matching delisting criteria ( 2 populations of 1,500 and 5 populations of 4,800 [15-year moving median]; U.S. Fish and Wildlife Service, 2019), quality of habitat is important. Modeling suggests 95 (95-percent confidence interval: 74-122) total acres are needed if the habitat is high quality with low (25 percent) total plant cover (figs. A2A, A15) and 1,369 (95-percent confidence interval: $1,017-1,842$ ) total acres are required if the habitat is highly invaded with high (90 percent) total plant cover (figs. A2C, A15). 


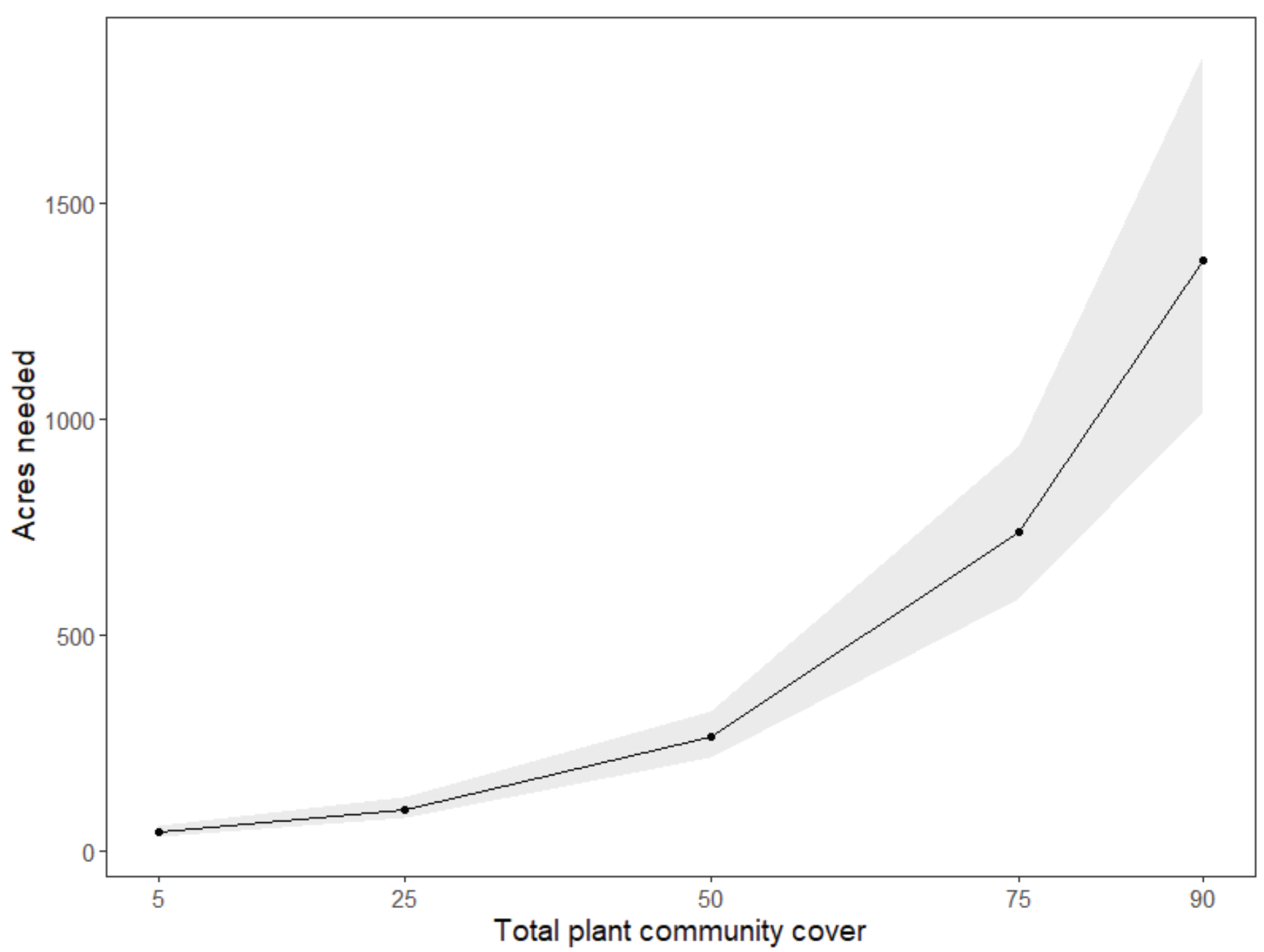

Figure A15. Total acres needed to sustain 2 populations of 1,500 and 5 populations of 4,800 adult howellii individuals $(27,000$ total adults) over ranges of total plant community cover. Increasing plant community cover exponentially increases acres needed to sustain populations.

\section{References Cited}

Atwater, B.F., 1982, Geologic factors in the prehistoric establishment of organisms endemic to eolian dunes near Antioch: California, U.S. Geological Survey, 6 p.

Cain, J., Beamish, S., Walkling, R., and Cheng, E., 2004, Dutch Slough Tidal Marsh restoration project preliminary opportunities and constraints report: Prepared by Natural Heritage Institute for the California State Coastal Conservancy, $63 \mathrm{p}$.

California Consortium of Herbaria, 2019, Entries for Oenothera deltoides subsp. howellii: California Consortium of Herbaria database, accessed 2019, at http://ucjeps.berkeley.edu/consortium/.
California Department of Fish and Wildlife, 2018, Entry for Oenothera deltoides subsp. howellii. California Natural Diversity Database: California Department of Fish and Wildlife, accessed 2018.

California Department of Parks and Recreation, 2019, Brannan Island state recreation area history, at Brannan Island state recreation area: California Department of Parks and Recreation web page, www.parks.ca.gov/?page_id $=1319$.

Center for Plant Conservation, 2014, Entry for Oenothera deltoides subsp. howellii. National Collection database: Center for Plant Conservation, accessed 2019.

East Bay Chapter of the California Native Plant Society, 2019, Entry for Oenothera deltoides subsp. howellii. Rare, Unusual, and Significant Plants of Alameda and Contra Costa Counties database: East Bay chapter of the California Native Plant Society, accessed 2019. 
Environmental Systems Research Institute (ESRI), 2011, ArcGIS Release 10.1: Redlands, Calif., Environmental Systems Research Institute, https://www.esri.com/en-us/home.

Greene, J.A., 1995, Three reproductive ecology studies in the narrow endemic Oenothera deltoides ssp. howellii (Onagraceae): Claremont, CA, Claremont Graduate University, $39 \mathrm{p}$.

Mathers, J., and U.S. Fish and Wildlife Service, 2018, Antioch Dunes national wildlife refuge 2017 vegetation inventory: Shelterbelt Builders Inc., 114 p.

McNally, A.M., 2014, Historical geography of the Antioch Dunes, Antioch, California, with a focus on current impacts to the habitat and population of the federally endangered Lange's Metalmark Butterfly (Apodemia mormo langei): Davis, Calif., University of California, 194 p.

Ontario Agricultural College BIO Herbarium, 2019, Entries for Oenothera deltoides subsp. howellii: BIO Herbarium at the University of Guelph, accessed 2019, at https://www.gbif.org/dataset.

Pavlik, B.M., and Manning, E., 1993, Assessing limitations on the growth of endangered plant populations, I. Experimental demography of Erysimum capitatum ssp. angustatum and Oenothera deltoides ssp. howellii: Biological Conservation, v. 65, no. 3, p. 257-265, https://doi.org/10.1016/0006-3207(93)90058-9.

Pavlik, B.M., Ferguson, N., and Nelson, M., 1993, Assessing limitations on the growth of endangered plant populations, II. Seed production and seed bank dynamics of Erysimum capitatum ssp. angustatum and Oenothera deltoides ssp. howellii: Biological Conservation, v. 65, no. 3, p. 267-278, https://doi.org/10.1016/0006-3207(93)90059-A.

Powell, J.A., 1983, Changes in the insect fauna of a deteriorating riverine sand dune community during 50 years of human exploitation: University of California Berkeley, $80 \mathrm{p}$.

R Core Team, 2016, R-A language and environment for statistical computing, ver. 3.2.2, https://www.R-project.org/.
Soil Survey Geographic Database, 2019, Web soil survey: Natural Resources Conservation Service, U.S. Department of Agriculture, accessed 2019, at https://websoilsurvey.nrcs.usda.gov/.

Stanford, B., Grossinger, R.M., Askevold, R.A., Whipple, A., Leidy, R.A., Beller, E.E., Salomon, M., and Striplen, C.J., 2011, East Contra Costa County historical ecology study: Oakland, Calif., San Francisco Estuary Institute 648, 126 p.

Thomson, D.M., 2005, Measuring the effects of invasive species on the demography of a rare endemic plant: Biological Invasions, v. 7, no. 4, p. 615-624, https://doi.org/10.1007/s10530-004-5853-3.

U.S. Fish and Wildlife Service, 1984, Revised recovery plan for three endangered species endemic to Antioch Dunes: California, U.S. Fish and Wildlife Service, 71 p.

U.S. Fish and Wildlife Service, 2002, Antioch Dunes national wildlife refuge comprehensive conservation plan. U.S. Fish and Wildlife Service, $86 \mathrm{p}$.

U.S. Fish and Wildlife Service, 2008, Lange's metalmark butterfly, Antioch Dunes evening-primrose, and Contra Costa wallflower 5-year review-Summary and evaluation: Sacramento, Calif., U.S. Fish and Wildlife Service, 37 p.

U.S. Fish and Wildlife Service, 2017, 2017 activities involving the Antioch Dunes Evening Primrose at Antioch Dunes National Wildlife Refuge: U.S. Fish and Wildlife Service unpublished data summary.

U.S. Fish and Wildlife Service, 2018, 2018 ADEP survey in New Dune site section 1: U.S. Fish and Wildlife Service unpublished data summary.

U.S. Fish and Wildlife Service, 2019, Recovery plan amendment - Revised recovery plan for three endangered species endemic to Antioch Dunes: California, San Francisco Bay-Delta Fish and Wildlife Office, Sacramento, California.

Wong, R., and Kolar, M., 2002, Wildlife fire management plan Antioch Dunes National Wildlife Refuge: U.S. Fish and Wildlife Service, $84 \mathrm{p}$. 


\section{Appendix A1. Additional Literature}

Evans, M.E.K., Hearn, D.J., Hahn, W.J., Spangle, J.M., and Venable, D.L., 2005, Climate and life-history evolution in evening primroses (Oenothera, Onagraceae) - A phylogenetic comparative analysis: Evolution; International Journal of Organic Evolution, v. 59, no. 9, p. 1914-1927, https://doi.org/10.1111/j.0014-3820.2005.tb01061.x.

Klein, W.M., 1962, New taxa and recombinations in Oenothera (Anogra): Aliso-A Journal of Systematic and Evolutionary Botany, v. 5, no. 2, p. 179-180.

\section{Appendix A2. Shapefiles of Individual Leica Real-Time Kinematic (RTK) Global Positioning System $(x, y)$ Location Points Taken at Off-Refuge Sites}

Available as an electronic file from https://doi.org/10.3133/ofr20211017. 


\section{Chapter B. Population Genomic Structure of the Endangered Antioch Dunes Evening- Primrose (Oenothera deltoides subsp. howellii) and Detection of a Potentially New Oenothera deltoides Taxon in Contra Costa County, California}

By Elizabeth R. Milano, Amy G. Vandergast

\section{Acknowledgments}

This work was supported by the U.S. Fish and Wildlife Service San Francisco Bay-Delta Fish and Wildlife, Friends of San Pablo Bay National Wildlife Refuge and Antioch Dunes National Wildlife Refuge, and the U.S. Geological Survey Western Ecological Research Center. Bioinformatic analyses were carried out on the Yeti Supercomputer: U.S. Geological Survey, https://doi.org/10.5066/F7D798MJ. We acknowledge Julia Smith from the U.S. Geological Survey Western Ecological Research Center, for assistance with genetic data collection. For help with occurrence logistics or general information, we would like to thank J. de la Cruz and J. McMurray from the city of Oakley; M. Ferrell from the California Department of Water Resources; L. Terrazas, D. Brubaker, S. Euing from U.S. Fish and Wildlife Service Antioch Dunes National Wildlife Refuge ; M. Moran and R. Pulizzi from Big Break Regional Shoreline; A. Janke from city of Walnut Creek; B. O'Brien, T. Fitanides, and B. Anderson from the Regional Parks Botanic Garden; R. O'Dell from the Bureau of Land Management; D. Lake from East Bay California Native Plant Society; T. Barry and E. Dean from the UC Davis Center for Plant Diversity Herbarium; the Contra Costa Water District; K. Heffernan and F. Takahashi from San Luis National Wildlife Refuge Complex; M. Hammond and C. Lare-Masters from East Bay Regional Park District; and V. Stewart from San Francisco Botanical Garden.

\section{Executive Summary}

- Our study goals were to assess the distribution of genetic diversity within and among occurrences of Oenothera deltoides subsp. howellii (hereafter, howellii) and explore its evolutionary relationship to a putative new taxon with an adjacent distribution using genome-wide genetic markers.

- We analyzed samples from eight howellii occurrences and from three occurrences of the unknown taxon on the Antioch sand sheet. These plants exhibited morphological characteristics intermediate between howellii and the closely related Oenothera deltoides subsp. cognata (hereafter, cognata). Samples from three cognata occurrences in the San Joaquin Valley also were included.

- Double-digest restriction-site associated deoxyribonucleic acid (DNA) sequencing resulted in 2,694 independent loci analyzed across 212 individuals distributed across 14 occurrences.

- Among howellii occurrences, genetic diversity was greatest at all three sampling locations on the Refuge.

- Population genomic structure analyses identified all howellii occurrences as a single genetic cluster and a second, unique cluster consisting of plants from Dutch Slough and two other occurrences on the Antioch sand sheet, hereafter, clade $\mathrm{X}$. These two genetic clusters were distinct from sampled occurrences of cognata.

- Phylogenetic analysis confirmed that these three groups form distinct, well-supported, monophyletic clades.

- We did not find any hybrid individuals or evidence of recent gene exchange between any of the three lineages.

\section{Introduction}

The Antioch Dunes evening-primrose (Oenothera deltoides subsp. howellii; hereafter howellii) is a subspecies of birdcage evening primrose (Oenothera deltoides; Onagraceae; Klein, 1962). Described subspecies within $O$. deltoides have disjunct distributions in habitats characterized by different California climate zones (Evans and others, 2009). Howellii's distribution is limited to the dunes near Antioch in a Mediterranean climate, whereas the nearest geographical clade member, $O$. deltoides subsp. cognata (hereafter cognata), has a much larger distribution in the San Joaquin Valley in a more arid and desert-like climate (Klein, 1970). Past climate conditions that brought the now-separate lineages together could have played a role in subspecies differentiation in the O. deltoides complex (Greene, 1995; Evans and others, 2009). Members of the species can be differentiated morphologically based on leaf, flower, and bud characteristics (Munz, 1949). 
When listed as federally endangered in 1978, there were small occurrences of howellii in the Antioch Dunes area of Contra Costa County, representing just 10 percent of the original riverine sand dune habitat (U.S. Fish and Wildlife Service, 2008). The majority of howellii are located on the Antioch Dunes National Wildlife Refuge (ADNWR), with smaller occurrences on Brannan Island, Browns Island, and in the Regional Parks Botanic Garden, all of which were outplanted in the 1970s (U.S. Fish and Wildlife Service, 2008). On ADNWR, population sizes generally decreased over the past three decades (U.S. Fish and Wildlife Service, 2020). However, very recently, plant abundance increased substantially on a sand dune restoration adjacent to existing plants on the Stamm Unit, suggesting that open, disturbed dune habitat is beneficial to this subspecies (chapter A). Regional surveys conducted in 2019 found a new, presumed natural occurrence of howellii on a small City of Oakley Parcel, designated as a preserve for legless lizards (chapter A). Furthermore, these surveys uncovered additional populations of birdcage evening-primrose that could not be keyed out. These plants had leaf and flower characteristics that appeared intermediate between howellii and cognata.

Given the small number and disjunct distribution of populations, a history of population declines, previous outplantings, and the possibility of a closely distributed related taxon or hybrid, an understanding of the genetic structure and diversity within howellii and in relation to its closest relatives could inform future management of this taxon. Estimates of genetic diversity can identify occurrences that would benefit from targeted restoration efforts as well as provide a snapshot for monitoring genetic diversity trends over time in response to future disturbances or restoration actions (Frankham and others, 2017). Population and phylogenetic structure can identify distinct genetic lineages and give insight into the geographic scale of gene flow (Hughes and others, 2008; Engelhardt and others, 2014). The genus Oenothera has a long history as a model organism for non-mendelian inheritance (Golczyk and others, 2008, 2014), cytoplasmic genetics (Chiu and Sears, 1993), and chromosome evolution (Cleland, 1972), among other topics (reviewed in, Johnson, 2011). However, no prior molecular genetic data exists for howellii, aside from a phylogeny of Oenothera sections Anogra and Kleinia (Onagraceae; Evans and others, 2005, 2009). Developing specific howellii genomic markers for population genomic analysis can play a key role in the conservation of this endangered taxon.

\section{Goals and Objectives}

This project was designed as a companion to the field surveys documenting distribution and abundance of howellii described in chapter A. Our study goals were to assess the distribution of genetic diversity within and among occurrences of howellii and explore its evolutionary relationship to the putative new taxon with an adjacent distribution on the Antioch sand sheet by using genome-wide genetic markers. Specifically, we:

- Describe genetic structure among surveyed occurrences of howellii,

- Describe patterns of genetic diversity within occurrences of howellii, and

- Investigate a putative new taxon in $O$. deltoides to determine if it represents a recent hybrid with cognata.

\section{Methods}

\section{Site Collections}

Leaf tissue was collected from all extant howellii occurrences (chapter A): Antioch Dunes National Wildlife Refuge (ADNWR Stamm dune in Management Area 1, Stamm excluding dune in Management Area 1, and Sardis Units considered separately), Brannan Island State Recreation Area, Browns Island, and City of Oakley Parcel (preserve for legless lizards). Samples also were collected from the Regional Parks Botanic Garden collection, and from cultivated plants obtained from Annie's Nursery (www.anniesannuals.com; Richmond, California).

At Dutch Slough, a site that was previously thought to contain howellii, plants were morphologically distinct from howellii observed at ADNWR and other occurrences. After consulting the Jepson manual (Baldwin and others, 2012) and herbarium specimens, it was determined that these plants appeared to have traits that were a mix between howellii and cognata (fig. B1). For example, these individuals showed dentate leaf margins with green, not gray-green, strigose foliage (cognata traits) but contained free sepal tips greater than 1 millimeter ( $\mathrm{mm}$; howellii traits). Dutch Slough individuals also contained more variability in traits than observed at other occurrences; leaf traits were especially variable among individuals within a population. Therefore, collections were expanded to survey any occurrences of this potential hybrid or new lineage in the local area and to survey the closest geographical subspecies, cognata. In total, six occurrences were collected in addition to the original howellii occurrences. Three of these occurrences (Dutch Slough, Oakley Rose Avenue, and Big Break) contained the morphological hybrid or new taxon (clade X), and cognata was collected from three occurrences further south in the Central Valley (Corral Hollow, Monvero Dunes North and South: fig. B2; table B1). Monvero Dunes samples were collected by Ryan O'Dell, Bureau of Land Management, Hollister Field Office. 

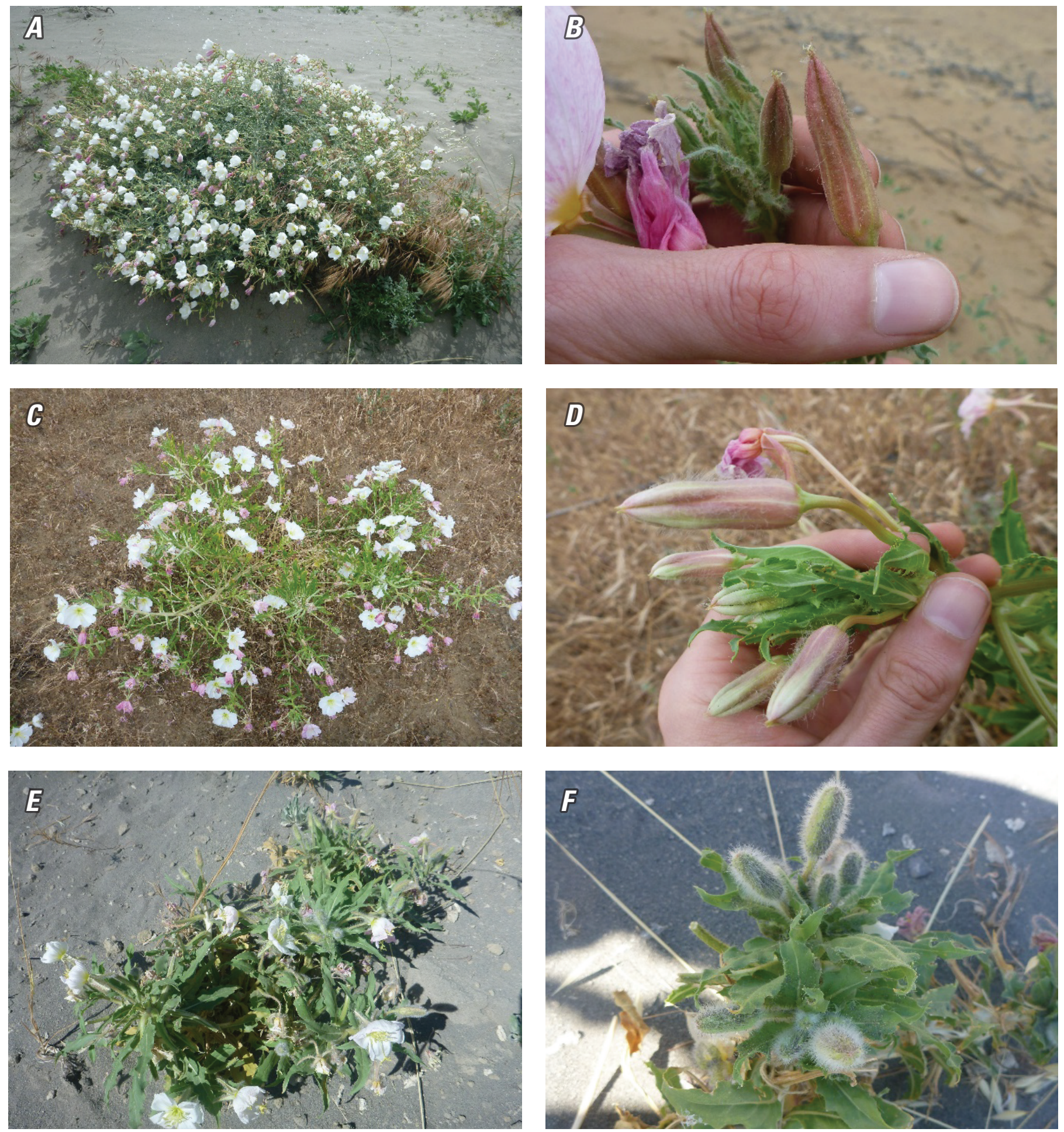

Figure B1. Variation in plant growth form and flower and sepal characteristics of the two described 0 . deltoides subspecies and the unknown clade included in this study. $A-B, 0$. d. subsp. howellii; $C-D$, clade $X ; E-F, 0$. d. subsp. cognata. Photographs taken by Scott F. Jones, U.S. Geological Survey, May 6, 2019, to June 12, 2019. 


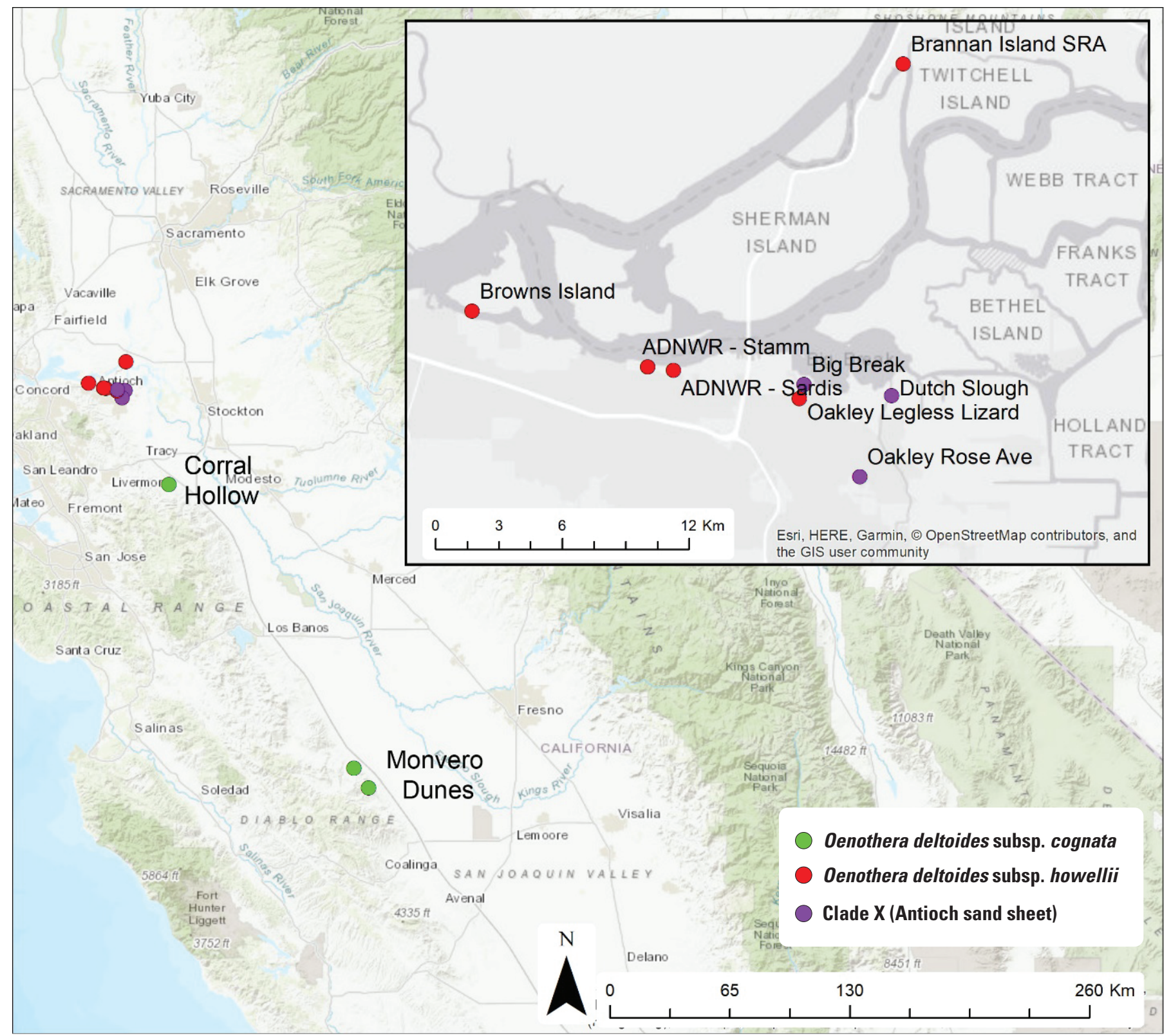

Map image is the intellectual property of Esri and is used herin under license. Copyright 2020 Esri and its licensors. All rights reserved.

Figure B2. Locations sampled for genomic analysis in May and June 2019. Insert shows close-up of sampled locations on and near the Antioch Dunes National Wildlife Refuge. 
Table B1. Occurrence summary table with type classification, location, sample size, and genetic diversity statistics.

[Occurrences with asterisks were out-planted from Antioch Dunes National Wildlife Refuge (ADNWR). Sample size is the number of individuals sampled at each occurrence, private alleles is the total number of allleles only found in that occurrence. Heterozygosity $\left(\mathrm{H}_{\mathrm{e}}\right)$ is the expected heterozygosity and inbreeding $\left(\mathrm{F}_{\mathrm{IS}}\right)$ is the inbreeding coefficient. Species: howellii, Oenothera deltoides subsp.; clade X, Antioch sand sheet; cognata, Oenothera deltoides subsp. Abbreviations: SE, standard error; NA, not available]

\begin{tabular}{lcccccccc}
\hline \multicolumn{1}{c}{ Occurrence name } & $\begin{array}{c}\text { Site } \\
\text { code }\end{array}$ & Type & Latitude & Longitude & $\begin{array}{c}\text { Sample } \\
\text { size }\end{array}$ & $\begin{array}{c}\text { Private } \\
\text { alleles }\end{array}$ & $\mathbf{H}_{\mathbf{e}}(\mathbf{S E})$ & $\mathbf{F}_{\mathbf{I S}}(\mathbf{S E})$ \\
\hline $\begin{array}{l}\text { Brown's Island* } \\
\text { ADNWR_Stamm Unit excluding } \\
\text { dune in Management Area 1 }\end{array}$ & BWI & Howellii & 38.03357472 & -121.8688585 & 10 & 14 & $0.096(0.003)$ & $-0.012(0.018)$ \\
ADNWR-Stamm Unit on-dune in & Howellii & 38.01525131 & -121.7932732 & 26 & 27 & $0.113(0.003)$ & $0.018(0.061)$ \\
$\quad$ Management Area 1 & ADU & Howellii & 38.01469852 & -121.7927105 & 26 & 8 & $0.112(0.003)$ & $0.0(0.033)$ \\
ADNWR-Sardis Unit & & & & & & & & \\
Oakley Legless Lizard Habitat & ASA & Howellii & 38.01364132 & -121.7835014 & 18 & 12 & $0.113(0.003)$ & $-0.001(0.037)$ \\
Brannan Island* & OLI & Howellii & 38.00419319 & -121.7300397 & 11 & 3 & $0.094(0.003)$ & $-0.029(0.022)$ \\
Annie's Nursery & BRI & Howellii & 38.11659249 & -121.6844055 & 19 & 8 & $0.094(0.003)$ & $0.004(0.056)$ \\
Regional Park Botanic Garden* & ANH & Howellii & NA & NA & 6 & 0 & $0.058(0.003)$ & $-0.032(0.015)$ \\
Big Break & RPB & Howellii & 37.892893 & -122.242802 & 7 & 1 & $0.093(0.003)$ & $-0.003(0.016)$ \\
Rose Avenue & BBR & Clade X & 38.00901534 & -121.7281286 & 7 & 45 & $0.113(0.003)$ & $0.016(0.013)$ \\
Dutch Slough & ORO & Clade X & 37.9777003 & -121.704666 & 20 & 52 & $0.106(0.003)$ & $-0.002(0.054)$ \\
Corral Hollow & DSL & Clade X & 38.00556027 & -121.6896543 & 17 & 101 & $0.117(0.003)$ & $0.016(0.03)$ \\
Monvero Dunes North & CHO & Cognata & 37.64289459 & -121.4773222 & 15 & 179 & $0.07(0.003)$ & $0.019(0.048)$ \\
Monvero Dunes South & MDN & Cognata & 36.53872461 & -120.5654169 & 12 & 177 & $0.107(0.003)$ & $0.035(0.032)$ \\
\hline & MDS & Cognata & 36.46407377 & -120.5039034 & 13 & 145 & $0.105(0.003)$ & $0.019(0.038)$ \\
\hline
\end{tabular}

\section{Extractions and Sequencing}

Leaf tissue for DNA analysis was collected from 20 individuals at each occurrence, where possible and 30 individuals from ADNWR Stamm unit occurrences. For each sample, three to five leaves were collected into coin envelopes in the field and transferred to a 45-degrees Celsius $\left({ }^{\circ} \mathrm{C}\right)$ oven until tissue was fully desiccated. Once dry, envelopes were stored with color-indicating silica gel desiccant in plastic bags inside a dessicator cabinet (Bel-Art, SP Scienceware, Wayne, New Jersey) at room temperature.

Genomic DNA was extracted using the E-Z 96® Plant DNA Kit (Omega Bio-tek Inc., Norcross, Georgia) with Antifoam Y-30 (Sigma-Aldrich, St. Louis, Missouri) added to the homogenizer plate and a 60-minute room temperature incubation before elution in 100 microliters $(\mu \mathrm{L})$ of water. Reduced representation genomic libraries were prepared using a modified double-digest restriction-site associated DNA sequencing (ddRAD) scheme (Peterson and others, 2012) in which 700 nanograms (ng) of DNA were digested with EcoRI and MseI restriction enzymes. In-line barcodes were ligated onto the EcoRI cut site and fragments were size-selected on a Pippin Prep (Sage Science, Inc., Beverly, Massachusetts) at a $400 \pm 30$ base pair (bp) range. Each library of 12 multiplexed samples was amplified by polymerase chain reactions (PCR) for 15 cycles with the addition of a unique library index sequence. Libraries were quantified, pooled, and sequenced at the University of California, Berkeley, Vincent J. Coates
Genomics Sequencing Lab (Berkeley, California) on two Illumina NovaSeq SP 100bp single-end lanes (Illumina, Inc., San Diego, California).

\section{Bioinformatics and Population Genomic Analyses}

Raw sequence trimming, demultiplexing, quality filtering, and genotyping was performed using Stacks v2.41 on the USGS Yeti High Performance Computing platform. Clustering, assembly, and filtering parameters were optimized using a subset of individuals following the $r 80$ method by Paris and others (2017). This subset was comprised of 30 percent of all samples evenly distributed across collection locations with read coverages that fell within 2 standard deviations of overall mean coverage per locus. This subset also was used to create a locus catalog (cstacks) for the full Stacks genotyping pipeline. The following parameters were used: maximum number of mismatches between stacks within individuals, $\mathrm{M}=3$; maximum number of mismatches between stacks between individuals, $\mathrm{n}=3$; minimum percentage of individuals across populations required to process a locus, $\mathrm{R}=0.65$ (Catchen and others, 2011). One single nucleotide polymorphism (SNP) was randomly chosen from each locus, exported in a variant call format (VCF) file, and further filtered for coverage depth by removing the bottom 1 percent, top 10 percent, and requiring 6 times the minimum coverage. 
Whitelists of loci and samples that passed the VCF filter were then rerun in the populations program to calculate genetic diversity statistics, including number of private alleles, expected heterozygosity $\left(\mathrm{H}_{\mathrm{e}}\right)$, inbreeding $\left(\mathrm{F}_{\mathrm{IS}}\right)$, and genetic differentiation among sampling locations $\left(\mathrm{F}_{\mathrm{ST}}\right)$.

Two genetic clustering analyses were used to explore the pattern of genetic structure among samples. A principal component analysis (PCA) was implemented in adegenet v2.1.3 (Jombart, 2008) by using R v3.6.3 (R Core Team, 2016) to visualize the genotypes in multidimensional space. FastSTRUCTURE v1.0, a Bayesian clustering method (Raj and others, 2014), was run for values of $\mathrm{K}$ from 1 to 10 to identify differences in allele frequencies across populations. A range of values for the optimal number of clusters (K) was determined using the chooseK.py script in the fastSTRUCTURE package. We report pairwise $\mathrm{F}_{\mathrm{ST}}$ and $\mathrm{H}_{\mathrm{e}}$ for the identified genetic clusters and tested for differences in $\mathrm{H}_{\mathrm{e}}$ by using the adegenet function Hs.test.

Field observations at clade X occurrences suggested that these plants had traits that were intermediate between howellii and cognata (fig. B1). We tested whether these plants represented an active hybrid zone between howellii and cognata, or a distinct taxon, using the likelihood optimization function snapclust in adegenet, with the option to explicitly model F1 (equal contributions of each parental population) and backcross (equal contributions of an F1 and a parental population) hybrids. To further investigate the lineage of clade $\mathrm{X}$, we used a maximum likelihood based phylogenetic approach implemented in Raxml v8.2.12 (Stamatakis, 2014) and executed in the CIPRES Science Gateway v3.3 (www.phylo.org). Briefly, a concatenated gene matrix was compiled for individuals with heterozygous sites coded using standard ambiguity codes. Analyses used a single model of evolution (General Time Reversible with a gamma distributed rate variation among sites; GTR $+\mathrm{g}$ ), were not partitioned, and were set to 100 rapid bootstrap inferences, before a thorough ML search. Resulting trees were visualized in FigTree v1.4 (https://github.com/rambaut/figtree/releases/tag/v1.4.4) and highly supported bootstrap values $(>80)$ were mapped onto the most likely tree. Finally, to identify genetic loci that discriminate among clusters, a discriminant analysis of principal components (DAPC) was used to maximize the differences between genetic clusters. To determine the optimal number of principal components (PCs) to retain, we used the interactive adegenet web server to perform a cross-validation procedure with the following settings: dataset split 90-percent training set, 10-percent validation set, 30 replicates, and selected the number of PCs with the lowest root mean squared error and highest mean successful assignments. We then used an average clustering threshold to identify SNPs that load onto each discriminant axis (DA).

\section{Results}

Sequenced raw read counts averaged $2.7 \times 10^{6} \pm 1.6 \times 10^{6}$ per individual. After quality filtering and dropping low coverage samples, average read coverage per locus was $25.0 \times \pm 6.0 \times$. The final genomic dataset included 207 individuals from 14 locations; 6 howellii occurrences, 3 clade X occurrences, 3 cognata occurrences, 1 howellii collection from a botanic garden, and 1 howellii collection from nursery stock (table B1). The dataset consisted of 2,694 independent loci with 15.41-percent missing data.

\section{Genetic Structure}

We found minimal population structure among howellii occurrences and found that clade $\mathrm{X}$ and cognata occurrences form distinct genetic clusters. The first principal component (PC1) of the PCA described 14.6 percent of the total genetic variation and $\mathrm{PC} 2$ described 6.22 percent. There was a clear pattern of three distinct clusters where the difference between cognata and howellii was attributed to PC1 and the difference between howellii and clade X was on PC2 (fig. B3). PC3 described 5.54 percent of the variation and distinguished the Corral Hollow and Monvero Dunes cognata occurrences (appendix B1). These three main clusters separated by principal component (PC) axes 1 and 2 were further supported by a fastSTRUCTURE analysis that found the optimal number of genetic clusters in the dataset was three. This analysis showed that clade $\mathrm{X}$ occurrences share some similarity with howellii but remain a distinct genetic group (fig. B4).

Similarly, estimates of genetic differentiation $\left(\mathrm{F}_{\mathrm{ST}}\right)$ were low among sampled howellii occurrences (range 0.02-0.096), especially the ADNWR locations. Notably, the Regional Park Botanic Garden (RBG) samples appeared least differentiated from the ADNWR locations. The Annie's Nursery (ANH) sample was the most differentiated from the howellii occurrences but this could be because of its unknown cultivation history. Pairwise differentiation estimates among all occurrences were highest between Corral Hollow and non-cognata occurrences (table B2). We also found that cognata was more differentiated from howellii and clade X, when samples were grouped by genetic cluster, (pairwise $\mathrm{F}_{\mathrm{ST}}$ for cognata-howellii=0.085, cognata-clade $\mathrm{X}=0.087$, howellii-clade $\mathrm{X}=0.043 ; \mathrm{p}<0.05$ ), rather than by occurrence. 


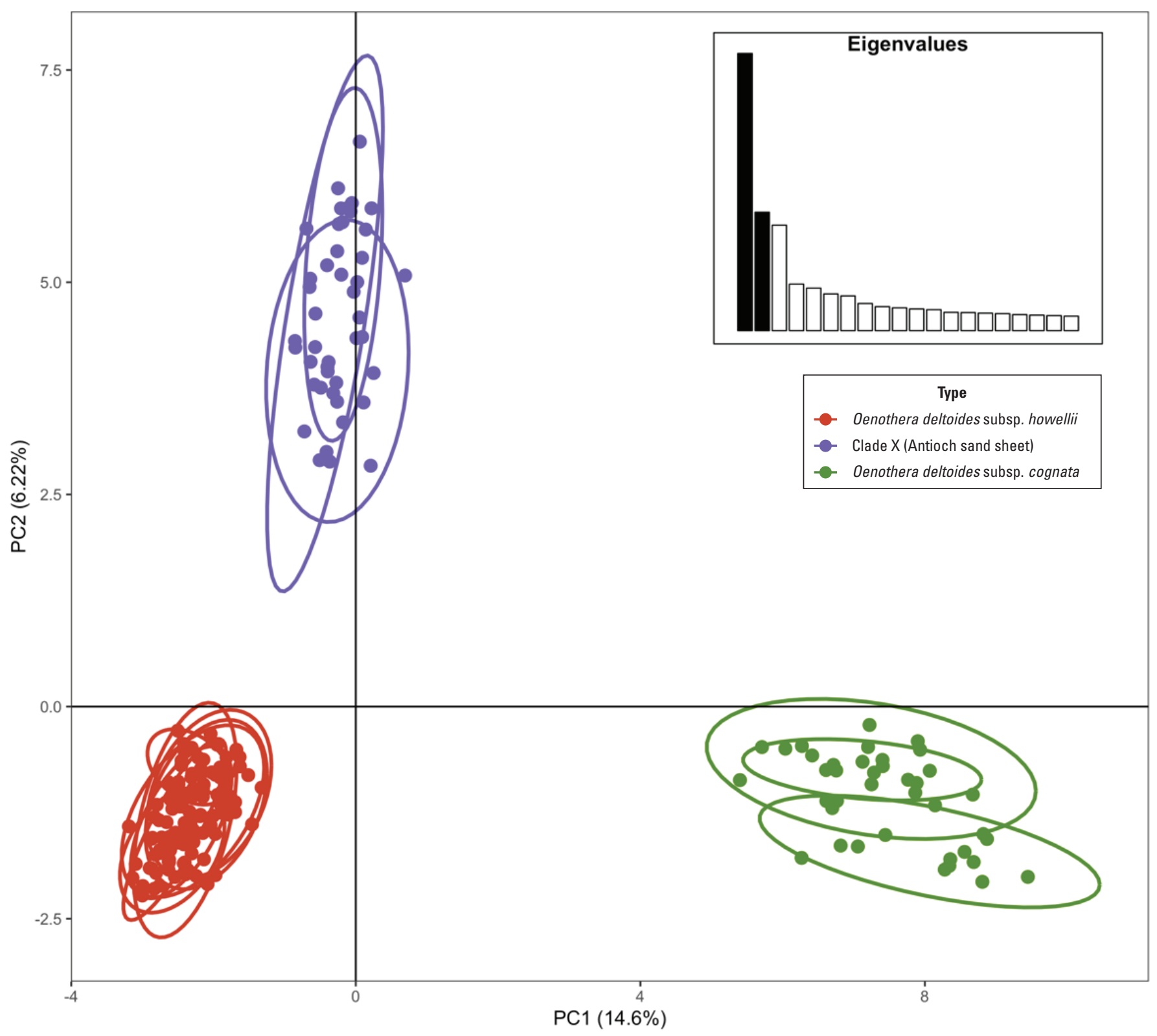

Figure B3. Principal component analysis where each point represents an individual, each ellipse represents a sampling occurrence, and color indicates type (red, howellii; purple, clade X; green, cognata). Eigenvalue inset shows relative proportion of variation explained by each principal component (PC) axis.

\section{Genetic Diversity}

Genetic diversity (expected heterozygosity $\left[\mathrm{H}_{\mathrm{e}}\right]$ ) for the sampled howellii occurrences ranged from $0.094 \pm 0.003$ standard error (SE) to $0.113 \pm 0.003 \mathrm{SE}$ (table B1). The three ADNWR occurrences had similar $\mathrm{H}_{\mathrm{e}}$ and were significantly higher than the remaining three occurrences; Browns Island, Brannan Island, and Oakley $(\mathrm{p}<0.001)$. Of the additional howellii collections, the RBG samples had a diversity estimate similar to the non-ADNWR occurrences (0.093) but the samples from ANH were much lower at 0.058 . Genetic diversity estimates for clade $\mathrm{X}$ and cognata occurrences were all above 0.1 with the exception of Corral Hollow $(0.07 \pm 0.003 \mathrm{SE})$. Inbreeding estimates $\left(\mathrm{F}_{\mathrm{IS}}\right)$ were essentially zero for all occurrences in the dataset (table B1).

When samples were considered by genetic cluster, rather than by occurrence (excluding samples from RBG and ANH because of unknown cultivation history), $\mathrm{H}_{\mathrm{e}}$ for cognata was significantly greater than clade $\mathrm{X}(\mathrm{p}<0.033)$ and howellii $(\mathrm{p}<0.037)$ and clade $\mathrm{X}$ was significantly greater than howellii $(\mathrm{p}<0.024)$. The number of private alleles found for each type was 351 (howellii), 328 (clade X), and 795 (cognata). These combined results indicated that cognata is more genetically diverse than howellii and clade $\mathrm{X}$, and clade $\mathrm{X}$ is more genetically diverse than howellii. 

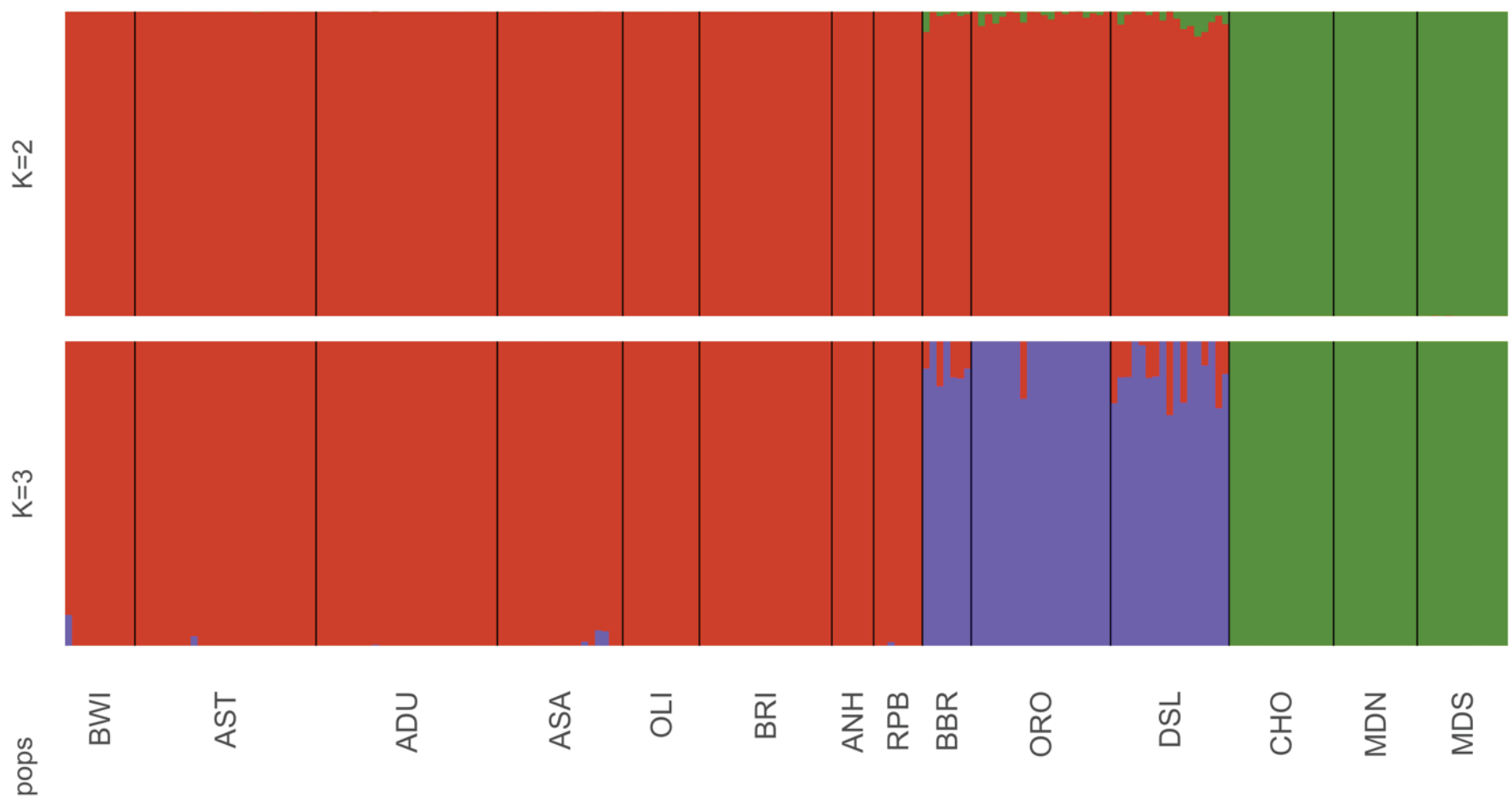

Figure B4. FastSTRUCTURE barplot where color indicates identity to each of $\mathrm{K}=3$ genetic clusters (orange, howellii; purple, clade X; green, cognata), black lines separate sampled occurrences, and narrow bars represent individuals. Occurrence codes in table B1.

\section{Potential Hybrids}

The snapclust hybrid model converged with no evidence of F1 or backcrossed hybrids at any location. Group membership probabilities for the three hybrid classes (F1, howellii-backcross, cognata-backcross) were statistically zero across the dataset, and all clade X samples were assigned to the howellii group (appendix B2). The maximum likelihood phylogenetic analysis strongly supported four clades, with howellii and clade X most closely related to each other and two clades within cognata that separated the two geographic locations sampled (fig. B5). There were no other well-supported clades within any of these lineages that corresponded with sampling sites within clades (appendix B3). These results, in addition to the population structure results, indicated that clade $\mathrm{X}$ is likely a separate distinct group from howelli and cognata with no indication of modern gene flow among these clades. However, we did find high genetic similarity and evidence of recent gene exchange or origin among occurrences within howellii and within clade X. Although the intermediate morphological features of clade $\mathrm{X}$ could indicate that this lineage was of hybrid origin, the genetic structure suggests it has since been isolated from each parental lineage for some time. Alternatively, a common ancestor of howellii and clade X could have first diverged from cognata and then howellii and clade $\mathrm{X}$ further diverged from each other.

Given these well-defined genetic clusters and the need for genetic identification in future taxonomic investigations, we used a discriminant analysis of principal components (DAPC; fig. B6) to identify the alleles with the highest contribution to the differences between each group. We found 22 SNPs that defined discriminant axis (DA) 1 , and 5 SNPs on DA 2. DA 1 differentiated cognata from remaining samples, and DA 2 differentiated clade X from howellii. The list of SNPs and the original 95bp locus sequences are included in appendix B4. 
[Color shading from low (white) to high (blue) values of genetic differentiation. All values significant at $p<0.05$. Abbreviations: AST, Antioch Dunes National Wildlife Refuge (ADNWR) - Stamm Unit excluding dune in Management Area 1; ADU, ADNWR—Stamm Unit on-dune in Management Area 1, ASA, ADNWR—Sardis Unit; OLI, Oakley Legless Lizard Habitat; BRI, Brannan Island; ANH, Annie's Nursery; RPB, Regional Park Botanic Garden; BBR, Big Break; ORO, Rose Avenue; DSL, Dutch Slough; CHO, Corral Hollow; MDN, Monvero Dunes North; MDS, Monvero Dunes South]

\begin{tabular}{|c|c|c|c|c|c|c|c|c|c|c|c|c|c|}
\hline AST & ADU & ASA & OLI & BRI & ANH & RPB & BBR & ORO & DSL & CHO & MDN & MDS & Site code \\
\hline \multirow[t]{13}{*}{0.039} & 0.046 & 0.048 & 0.096 & 0.084 & 0.138 & 0.085 & 0.111 & 0.111 & 0.091 & 0.245 & 0.171 & 0.164 & BWI \\
\hline & 0.021 & 0.021 & 0.044 & 0.04 & 0.06 & 0.037 & 0.065 & 0.076 & 0.067 & 0.172 & 0.126 & 0.124 & AST \\
\hline & & 0.02 & 0.053 & 0.053 & 0.068 & 0.043 & 0.071 & 0.085 & 0.071 & 0.183 & 0.136 & 0.133 & ADU \\
\hline & & & 0.057 & 0.055 & 0.076 & 0.042 & 0.069 & 0.081 & 0.067 & 0.182 & 0.132 & 0.129 & ASA \\
\hline & & & & 0.087 & 0.162 & 0.099 & 0.124 & 0.113 & 0.101 & 0.257 & 0.177 & 0.172 & OLI \\
\hline & & & & & 0.126 & 0.091 & 0.108 & 0.113 & 0.103 & 0.237 & 0.171 & 0.168 & BRI \\
\hline & & & & & & 0.176 & 0.161 & 0.127 & 0.117 & 0.317 & 0.216 & 0.208 & ANH \\
\hline & & & & & & & 0.114 & 0.106 & 0.088 & 0.253 & 0.173 & 0.166 & RPB \\
\hline & & & & & & & & 0.04 & 0.052 & 0.212 & 0.148 & 0.145 & BBR \\
\hline & & & & & & & & & 0.065 & 0.199 & 0.145 & 0.143 & ORO \\
\hline & & & & & & & & & & 0.186 & 0.134 & 0.133 & DSL \\
\hline & & & & & & & & & & & 0.167 & 0.168 & $\mathrm{CHO}$ \\
\hline & & & & & & & & & & & & 0.043 & MDN \\
\hline
\end{tabular}




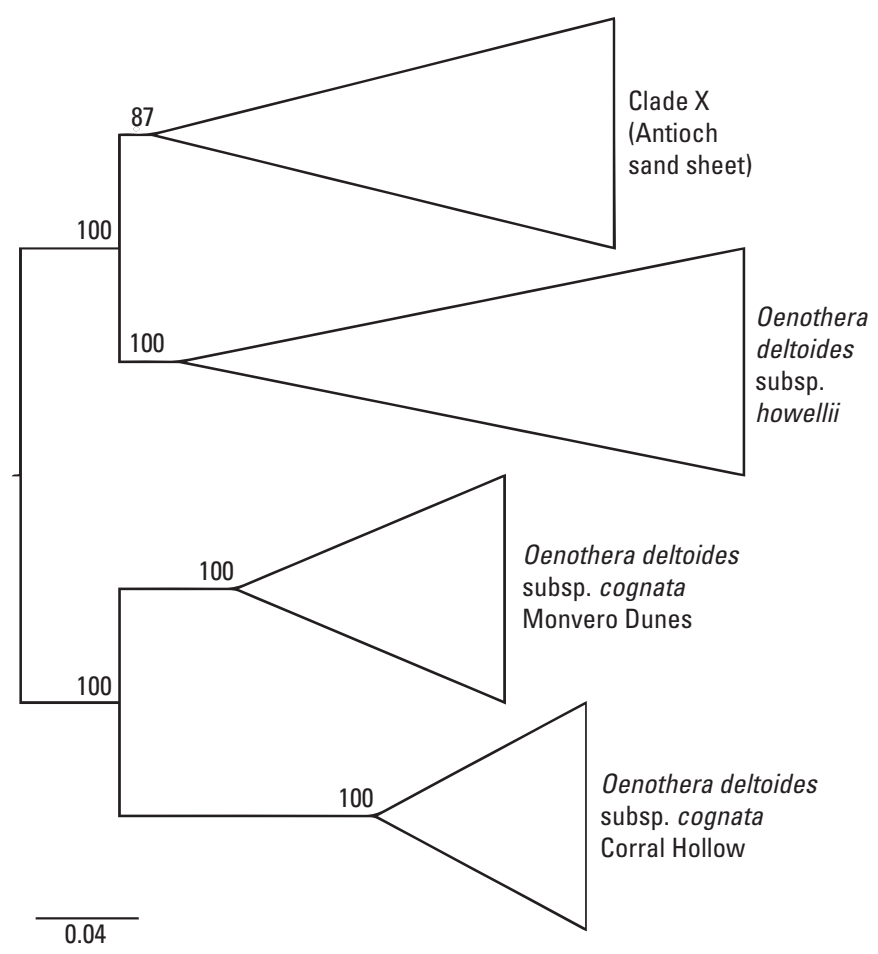

Figure B5. Maximum likelihood tree collapsed at nodes with high bootstrap support. All morphologically distinguishable taxa form highly supported unique clades (clade $\mathrm{X}$, howellii, and cognata). Support also was high separating the two distinct geographic populations that were sampled within cognata (Monvero Dunes and Corral Hollow). Because these occurrences are at opposite ends of the known cognata range, these differences could represent clinal variation within this taxon.

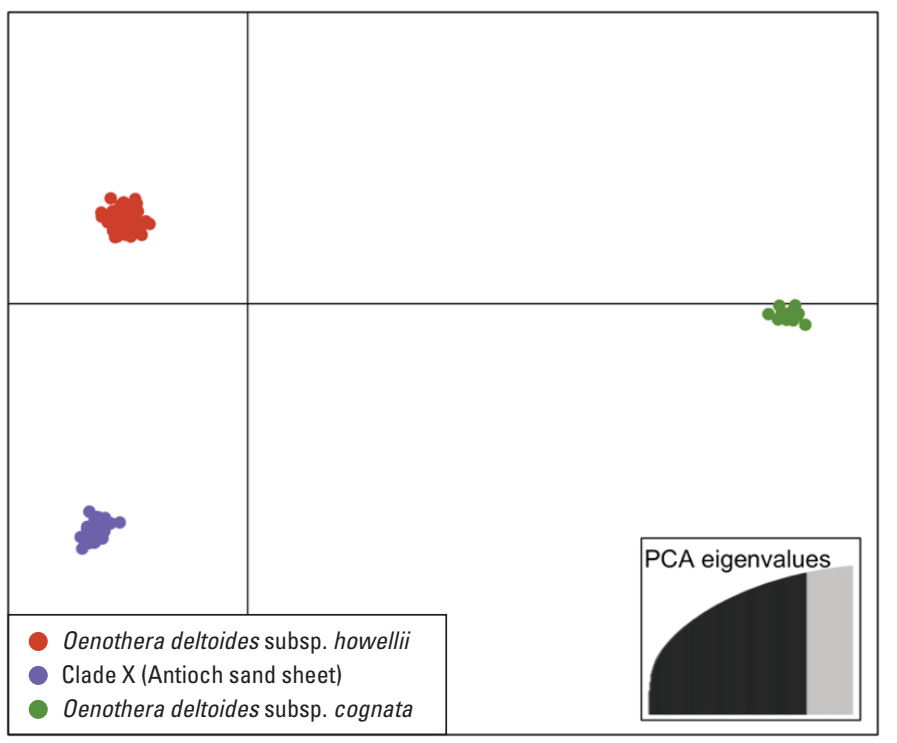

Figure B6. Discriminant analysis of principal components (DAPC) plot maximizing differences between genetic clusters (red, howellii; purple, clade X; green, cognata). Inset shows proportion of principal components retained in analysis.

\section{Discussion}

We found evidence of two distinct genetic clusters on the Antioch sand sheet, supporting that there are two taxa present with distinctive morphological and genetic features; howellii and clade X. Within howellii, genetic diversity was lowest for the smaller howellii occurrences, and higher for the ANDWR occurrences, which is consistent with reported out-plantings at Browns and Brannan Islands that used plant material sourced from ANDWR (U.S. Fish and Wildlife Service, 2008). If there is a future need to manage or restore Browns and Brannan Islands occurrences, sourcing materials from ANDWR could help to boost genetic diversity in these occurrences. The Oakley location is the only natural howellii occurrence without a known origin of source material from ANDWR, and though it is clearly howellii, it was found to be more genetically distant from the ANDWR and ANDWR-derived occurrences. This occurrence was relatively small, with only four adult plants detected at the time of survey, although juvenile plants suggest some recruitment. The small sample from Annie's Nursery appears to be most genetically distant from the non-cultivated howellii occurrences. The natural source of these plants and the number of generations in cultivation are unknown and likely contribute to this relative distinctiveness. As such, these plants do not appear to be an important source of diversity relevant to the existing natural and out-planted occurrences.

The remaining three sampled locations on the Antioch sand sheet exclusively contained individuals of the morphologically distinctive clade X. All of our population and phylogenetic analyses indicated that this clade appears to be more closely related to howellii than to cognata and that it does not show evidence of recent hybridization or gene flow with either howellii or cognata. Notably, no surveyed occurrences contained more than one clade. Even the two closest occurrences (Oakley legless lizard population of howellii and the Big Break clade X population), which are less than 1 kilometer apart, showed no mixed assignment. Although clade X may be of hybrid origin, it is possible that a genome structural mutation or non-Mendelian pattern of inheritance resulted in incompatibility between lineages. Chromosomal rearrangements and permanent translocation heterozygosity are well documented in the genus Oenothera (Holsinger and Ellstrand, 1984; Johnson, 2011). Because there is no evidence of recent hybridization, potential hybridization between howellii and clade $\mathrm{X}$ is likely not a threat to extant howellii occurrences, although morphological traits of plants in extant howellii occurrences could be periodically monitored to detect any range changes in howellii and clade X. 
Regardless of origin, clade X could represent new, previously undescribed diversity in the $O$. deltoides lineage that could benefit from protection given that it appears to have a limited range. To further resolve the taxonomic status of the unidentified clade, we suggest a two-pronged approach. The first step is conducting more in-depth morphological and phylogenetic analyses on the entire $O$. deltoides species complex. Some of the identifying morphological traits in this clade appear to be plastic; therefore, careful analysis of these particular traits in sister taxa may clarify the use of those traits as defining characteristics. An expanded phylogenetic analysis of the entire species complex with nuclear markers and increased marker density could better resolve the relationships between taxa and confirm the placement of clade $\mathrm{X}$. The original phylogeny of Oenothera, sections Anogra and Kleinia was based on plastid gene sequences (Evans and others, 2005, 2009), however there are known confounding interactions between nuclear and chloroplast genomes within Oenothera (Chiu and Sears, 1993) that may affect phylogenetic interpretation. We have demonstrated that over 2,500 genomic loci can be developed by using a ddRADseq approach and identified a set of markers that can be used to distinguish these 3 independent clades. It is possible to extend this method for the $O$. deltoides species complex. In the second step, demographic modeling could be used to explore the age of each lineage and estimate historical population sizes and migration rates between the groups. These models can be used to test hypotheses of historical hybridization events and the evolutionary history of this group. Finally, should these additional analyses support clade $\mathrm{X}$ as a new Oenothera deltoides lineage, expanding surveys of the Antioch sand sheet could uncover more occurrences and extend the known range of this taxon.

\section{References Cited}

Baldwin, B.G., Goldman, D., Keil, D.J., Patterson, R., and Rosatti, T.J., eds., 2012, The jepson manual-Vascular plants of California: University of California Press, 1596 p., https://doi.org/10.1525/9780520951372.

Catchen, J.M., Amores, A., Hohenlohe, P., Cresko, W., and Postlethwait, J.H., 2011, Stacks-Building and genotyping loci de novo from short-read sequences: G3-Genes, Genomes, Genetics, v. 1, no. 3, p. 171-182, https://doi.org/10.1534/g3.111.000240.

Chiu, W.L., and Sears, B.B., 1993, Plastome-genome interactions affect plastid transmission in Oenothera: Genetics, v. 133, no. 4, p. 989-997, https://doi.org/10.1093/genetics/133.4.989.

Cleland, R.E., 1972, Oenothera; Cytogenetics and Evolution: London, New York, Academic Press.

Engelhardt, K.A.M., Lloyd, M.W., and Neel, M.C., 2014, Effects of genetic diversity on conservation and restoration potential at individual, population, and regional scales: Biological Conservation, v. 179, p. 6-16, https://doi.org/10.1016/j.biocon.2014.08.011.

Evans, M.E.K., Hearn, D.J., Hahn, W.J., Spangle, J.M., and Venable, D.L., 2005, Climate and life-history evolution in evening primroses (Oenothera, Onagraceae)-A phylogenetic comparative analysis: Evolution; International Journal of Organic Evolution, v. 59, no. 9, p. 1914-1927, https://doi.org/10.1111/j.0014-3820.2005.tb01061.x. 
Evans, M.E.K., Smith, S.A., Flynn, R.S., and Donoghue, M.J., 2009, Climate, niche evolution, and diversification of the "bird-cage" evening primroses (Oenothera, Sections Anogra and Kleinia): American Naturalist, v. 173, no. 2, p. 225-240, https://doi.org/10.1086/595757.

Frankham, R., Ballou, J.D., Ralls, K., Eldridge, M.D.B., Dudash, M.R., Fenster, C.B., Lacy, R.C., and Sunnucks, P., 2017, Genetic management of fragmented animal and plant populations: Oxford, Oxford University Press, 401 p., https://doi.org/10.1093/oso/9780198783398.001.0001.

Golczyk, H., Massouh, A., and Greiner, S., 2014, Translocations of chromosome end-segments and facultative heterochromatin promote meiotic ring formation in evening primroses: The Plant Cell, v. 26, no. 3, p. 1280-1293, https://doi.org/10.1105/tpc.114.122655.

Golczyk, H., Musiał, K., Rauwolf, U., Meurer, J., Herrmann, R.G., and Greiner, S., 2008, Meiotic events in Oenothera - A non-standard pattern of chromosome behaviour: Genome, v. 51, no. 11, p. 952-958, https://doi.org/10.1139/G08-081.

Greene, J.A., 1995, Three reproductive ecology studies in the narrow endemic Oenothera deltoides ssp. howellii (Onagraceae): Claremont, CA, Claremont Graduate University, $39 \mathrm{p}$.

Holsinger, K.E., and Ellstrand, N.C., 1984, The evolution and ecology of permanent translocation heterozygotes: American Naturalist, v. 124, no. 1, p. 48-71, https://doi.org/10.1086/284251.

Hughes, A.R., Inouye, B.D., Johnson, M.T.J., Underwood, N., and Vellend, M., 2008, Ecological consequences of genetic diversity: Ecology Letters, v. 11, no. 6, p. 609-623, https://doi.org/10.1111/j.1461-0248.2008.01179.x.

Johnson, M.T.J., 2011, The contribution of evening primrose (Oenothera biennis) to a modern synthesis of evolutionary ecology: Population Ecology, v. 53, no. 1, p. 9-21, https://doi.org/10.1007/s10144-010-0250-5.

Jombart, T., 2008, adegenet-A R package for the multivariate analysis of genetic markers: Bioinformatics (Oxford, England), v. 24, no. 11, p. 1403-1405, https://doi.org/10.1093/bioinformatics/btn129.
Klein, W., 1962, New taxa and recombinations in Oenothera (Anogra): Aliso-A Journal of Systematic and Evolutionary Botany, v. 5, no. 2, p. 179-180.

Klein, W.M., 1970, The evolution of three diploid species of Oenothera Subgenus Anogra (Onagraceae): Evolution; International Journal of Organic Evolution, v. 24, no. 3, p. 578-597, https://doi.org/10.1111/j.1558-5646.1970.tb01793.x.

Munz, P., 1949, California miscellany-I: Aliso, v. 2, no. 1, p. 77-86, https://doi.org/10.5642/aliso.19490201.05.

Paris, J.R., Stevens, J.R., and Catchen, J.M., 2017, Lost in parameter space-A road map for stacks: Methods in Ecology and Evolution, v. 8, no. 10, p. 1360-1373, https://doi.org/10.1111/2041-210X.12775.

Peterson, B.K., Weber, J.N., Kay, E.H., Fisher, H.S., and Hoekstra, H.E., 2012, Double digest RADseq-An inexpensive method for de novo SNP discovery and genotyping in model and non-model species: PLoS One, v. 7, no. 5, 11 p., https://doi.org/10.1371/journal.pone.0037135.

R Core Team, 2016, R-A language and environment for statistical computing, ver. 3.2.2: R Foundation for Statistical Computing software release, https:/www.R-project.org/.

Raj, A., Stephens, M., and Pritchard, J.K., 2014, fastSTRUCTURE-Variational inference of population structure in large SNP data sets: Genetics, v. 197, no. 2, p. 573-589, https://doi.org/10.1534/genetics.114.164350.

Stamatakis, A., 2014, RAxML version 8-A tool for phylogenetic analysis and post-analysis of large phylogenies: Bioinformatics (Oxford, England), v. 30, no. 9, p. 1312-1313, https://doi.org/10.1093/bioinformatics/btu033.

U.S. Fish and Wildlife Service, 2008, Lange's metalmark butterfly, Antioch Dunes evening-primrose, and Contra Costa wallflower 5-year review-Summary and evaluation: Sacramento, Calif., U.S. Fish and Wildlife Service, 37 p.

U.S. Fish and Wildlife Service, 2020, Five year review for the Antioch Dunes evening-primrose (Oenothera deltoides subsp. howellii): Sacramento, Calif., Sacramento Fish and Wildlife Office, $21 \mathrm{p}$. 


\section{Appendix B1. Supplemental Principal Component Analysis Plot}

PC3 describes the variation between cognata sampling locations Corral Hollow in the north and both Monvero Dunes locations in the south. (fig. B1.1).

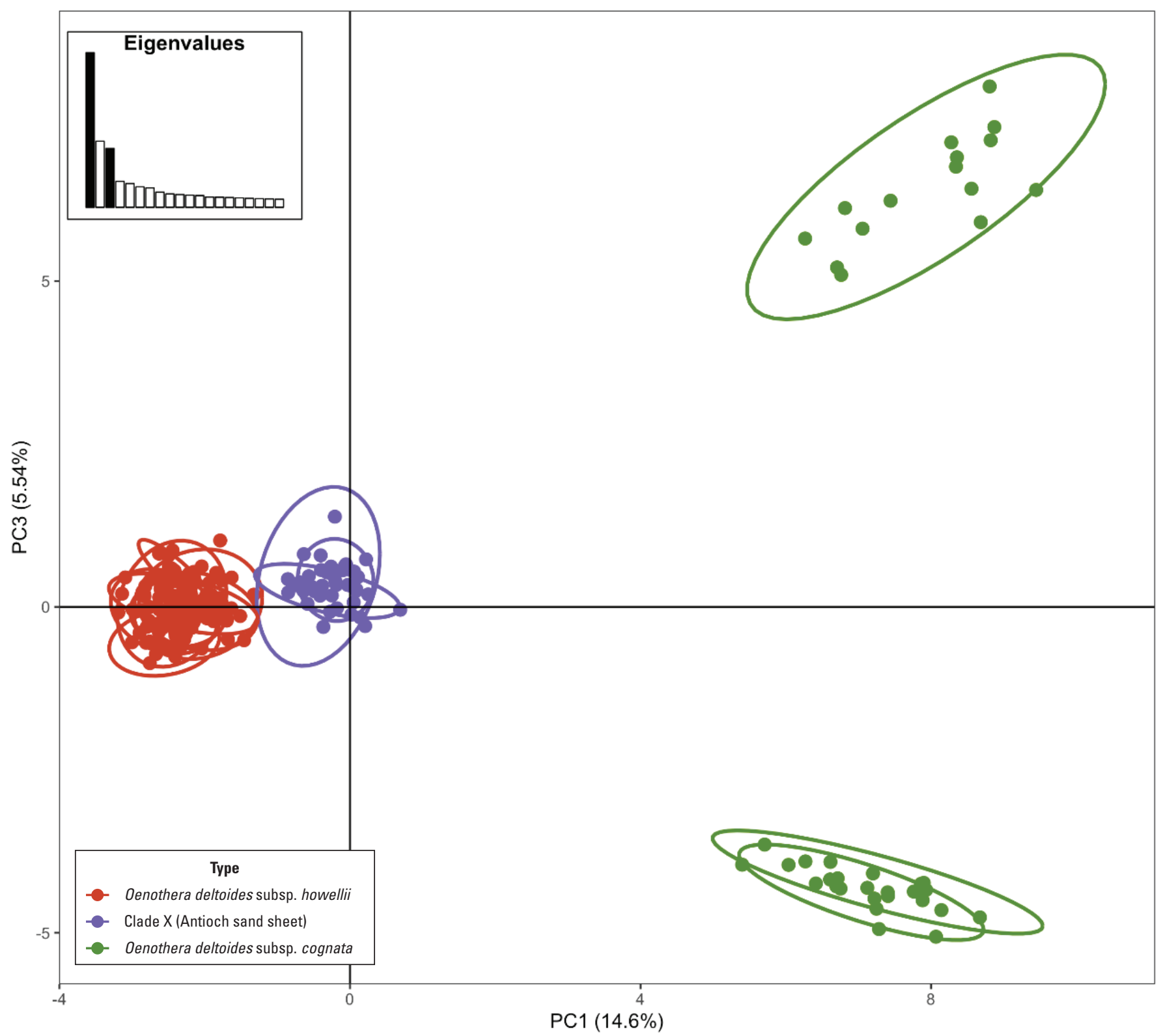

Figure B1.1. Principal component analysis plot of PC1 and PC3 where each point represents an individual, each ellipse represents a sampling location, and color indicates type (red, howellii; purple, clade X; green, cognata). Eigenvalue inset shows relative proportion of variation explained by each principal component (PC) axis.

\section{Appendix B2. Snapclust Hybrid Test Results}

Table B2.1. Group membership probabilities by sample, available at https://doi.org/10.3133/ofr20211017. 


\section{Appendix B3. Maximum Likelihood Tree}

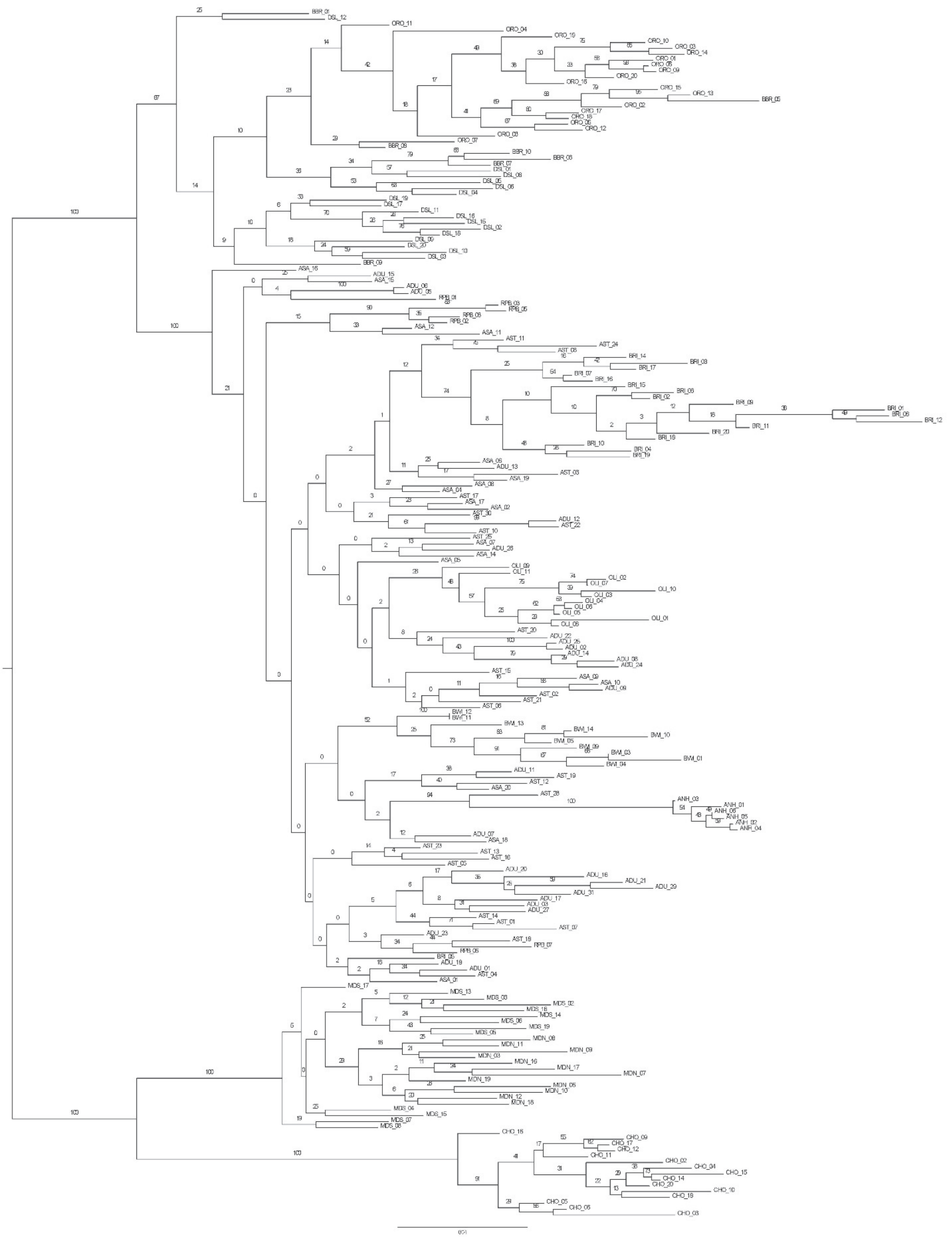

Figure B3.1. Full maximum likelihood tree with bootstrap support values at nodes. 


\section{Appendix B4. Discriminate Analysis of Principal Components Results}

Table B4.1. Allele frequencies for discriminate analysis of principal components informative loci.

[DA, discriminate axis; SNP, single nucleotide polymorphism. Allele: A, adenine; T, thymine; C, cytosine; G, guanine]

\begin{tabular}{|c|c|c|c|c|c|c|}
\hline DA Axis & Locus & SNP position & Allele & howellii frequency & clade $X$ frequency & cognata frequency \\
\hline 1 & 1675 & 17 & $\mathrm{C}$ & 1 & 1 & 0.5 \\
\hline 1 & 1675 & 17 & $\mathrm{~T}$ & 0 & 0 & 0.5 \\
\hline 1 & 5951 & 81 & $\mathrm{~A}$ & 0.12704918 & 0.162790698 & 0.925 \\
\hline 1 & 8298 & 36 & A & 0.813559322 & 0.837209302 & 0 \\
\hline 2 & 11136 & 40 & A & 0.71875 & 0.083333333 & 1 \\
\hline 2 & 11136 & 40 & $\mathrm{~T}$ & 0.28125 & 0.916666667 & 0 \\
\hline 2 & 14084 & 19 & $\mathrm{C}$ & 0.372881356 & 0.941860465 & 0.960526316 \\
\hline 2 & 14084 & 19 & G & 0.627118644 & 0.058139535 & 0.039473684 \\
\hline 1 & 15139 & 35 & $\mathrm{~T}$ & 0.984042553 & 1 & 0.6 \\
\hline 2 & 18527 & 14 & G & 0.803921569 & 0.042857143 & 0.283783784 \\
\hline 2 & 18527 & 14 & A & 0.196078431 & 0.957142857 & 0.716216216 \\
\hline 1 & 24555 & 73 & A & 0.454545455 & 0.078947368 & 0.944444444 \\
\hline 1 & 24555 & 73 & $\mathrm{C}$ & 0.545454545 & 0.921052632 & 0.055555556 \\
\hline 2 & 24703 & 48 & $\mathrm{~T}$ & 0.873786408 & 0.073170732 & 0 \\
\hline 2 & 24703 & 48 & $\mathrm{C}$ & 0.126213592 & 0.926829268 & 1 \\
\hline 1 & 25273 & 69 & A & 1 & 1 & 0.026315789 \\
\hline 1 & 25273 & 69 & G & 0 & 0 & 0.973684211 \\
\hline 1 & 34130 & 19 & G & 0.5 & 0.329545455 & 1 \\
\hline 1 & 34130 & 19 & A & 0.5 & 0.670454545 & 0 \\
\hline 1 & 34986 & 41 & A & 0.7625 & 0.090909091 & 1 \\
\hline 1 & 34986 & 41 & $\mathrm{C}$ & 0.2375 & 0.909090909 & 0 \\
\hline 2 & 42124 & 14 & A & 0.668032787 & 0.321428571 & 0.325 \\
\hline 2 & 42124 & 14 & G & 0.331967213 & 0.678571429 & 0.675 \\
\hline 1 & 42661 & 85 & $\mathrm{C}$ & 0.867768595 & 1 & 0.225 \\
\hline 1 & 42661 & 85 & $\mathrm{~T}$ & 0.132231405 & 0 & 0.775 \\
\hline 1 & 44259 & 11 & $\mathrm{~T}$ & 0.431623932 & 0.686046512 & 0 \\
\hline 1 & 44259 & 11 & $\mathrm{C}$ & 0.568376068 & 0.313953488 & 1 \\
\hline 1 & 47505 & 46 & A & 0.967213115 & 1 & 0 \\
\hline 1 & 47505 & 46 & $\mathrm{~T}$ & 0.032786885 & 0 & 1 \\
\hline
\end{tabular}


Table B4.1. Allele frequencies for discriminate analysis of principal components informative loci.-Continued [DA, discriminate axis; SNP, single nucleotide polymorphism. Allele: A, adenine; T, thymine; C, cytosine; G, guanine]

\begin{tabular}{ccccccc}
\hline DA Axis & Locus & SNP position & Allele & howellii frequency & clade X frequency & cognata frequency \\
\hline 1 & 52208 & 14 & $\mathrm{~T}$ & 0.577669903 & 0.931034483 & 0 \\
1 & 52208 & 14 & $\mathrm{G}$ & 0.422330097 & 0.068965517 & 1 \\
1 & 53441 & 45 & $\mathrm{G}$ & 1 & 1 & 0.487179487 \\
1 & 53441 & 45 & $\mathrm{~T}$ & 0 & 0 & 0.512820513 \\
1 & 53792 & 57 & $\mathrm{~A}$ & 1 & 1 & 0.462962963 \\
1 & 53792 & 57 & $\mathrm{G}$ & 0 & 0 & 0.537037037 \\
1 & 54384 & 72 & $\mathrm{~T}$ & 1 & 1 & 0.15625 \\
1 & 54384 & 72 & $\mathrm{C}$ & 0 & 0 & 0.84375 \\
1 & 62956 & 23 & $\mathrm{G}$ & 1 & 1 & 0.371794872 \\
1 & 62956 & 23 & $\mathrm{C}$ & 0 & 0 & 0.628205128 \\
1 & 63998 & 88 & $\mathrm{C}$ & 0.99047619 & 1 & 0 \\
1 & 63998 & 88 & $\mathrm{~T}$ & 0.00952381 & 0 & 1 \\
1 & 68215 & 81 & $\mathrm{G}$ & 0.991150442 & 0.618421053 & 0 \\
1 & 68215 & 81 & $\mathrm{~T}$ & 0.008849558 & 0.381578947 & 1 \\
\hline
\end{tabular}

Table B4.2. Consensus 95bp sequence for discriminate analysis of principal components informative loci.

\begin{tabular}{|c|c|}
\hline Locus & Sequence \\
\hline 1675 & $\begin{array}{l}\text { AATTCGTCGGAGCGCGCGATTCTTTCAGGCCATCCGGCGGCAAAACGGCGACTCTTGAGGCTTCCGGACCAGCTATTG } \\
\text { GGGTTTCGCGAAGTTTC }\end{array}$ \\
\hline 5951 & $\begin{array}{l}\text { AATTCAAGTCTCTTCCTTGGACATGAACTGTCAAACAACTGCAGAAGAAGACAAGGCATGTTTTAGCAGTAAGAGGGT } \\
\text { TTGTCTTGGACATATTT }\end{array}$ \\
\hline 8298 & $\begin{array}{l}\text { AATTCTCAAGTCCAACAAAGGTTCCTTCATGGCATAAAAAATCTCTCCTACCTATCAAAGCAGGAGATGACATCTACTT } \\
\text { GTATAATAATTCTATT }\end{array}$ \\
\hline 15139 & $\begin{array}{l}\text { AATTCTCTGACACCAATCACCTTTGTCAAAAGCCTTACCCCCTCTCTAAGAATGAATGTTTGAACCAAACTTCAAAAAA } \\
\text { TCCCTCTCTTTTTTAT }\end{array}$ \\
\hline 16696 & $\begin{array}{l}\text { AATTCCTTACTTCTCAGAAATGCTTGCTTCAAATCAAAGAAAGAAGATCCATTATTCCACGTACTTGGCAGGTTAGCGA } \\
\text { CAGAAAATCCCCATCA }\end{array}$ \\
\hline 24555 & $\begin{array}{l}\text { AATTCCCTTCTTCTCCATGACTATTCGTGCCAATTCTTCCACGCTGCTATTTTGATTTCTGTATCAAAATGCAAAATTGAA } \\
\text { TGGAATAACCAATA }\end{array}$ \\
\hline 25273 & $\begin{array}{l}\text { AATTCAGAAAATAATAAATGAGCTTCCTCGGAGTAGTTTCTAGTTGAGTGAAACACTGTGCCTCCTGGCTCCTGGCCTA } \\
\text { GCCTGCTGTAAATGCA }\end{array}$ \\
\hline 26807 & $\begin{array}{l}\text { AATTCTACATATCGGCAACAAGAGTTGCCTCTGAAGAGTGTCCAGTGTTCCTTTTTTCTTTTTGTTGTTTTGAAGTATTG } \\
\text { TTTTATGTATCACAT }\end{array}$ \\
\hline 30501 & $\begin{array}{l}\text { AATTCTAAGGAGGAGGCAGCAGCGCGCCAAGCTCGAGGCTCAGAACAAACTTGCAAAAGATCGCAAGGTTTCCTTTC } \\
\text { CTATCTCTCTCGCTCACT }\end{array}$ \\
\hline 33198 & $\begin{array}{l}\text { AATTCTATTCTCCGTTTACAGTGCTGAGAGAAAAAGAAAGATAATGTTTCTGACCTGAACGTCGAATTCGATGAAGTCG } \\
\text { ATTGGGAACTTGGCGG }\end{array}$ \\
\hline 34130 & $\begin{array}{l}\text { AATTCAATCGAAAGTGACAAGAATATCATACATTTGTACCATCAAATCCCATTTTAGTATCCACAGAAAATAAAAGAACT } \\
\text { AAAATAGGAAGATTA }\end{array}$ \\
\hline 34986 & $\begin{array}{l}\text { AATTCCAATTAGACCTAGGATCTGGCTGATGCGGTAGATCCTGGTGATGGAAATGATGGGTCTGACTAATAAAACTTGG } \\
\text { GTAGCTGCGCTTTCGA }\end{array}$ \\
\hline 42661 & $\begin{array}{l}\text { AATTCCTACTGAAATCGCCAACTTATATATGATTAGTAAGATTAGGAAAAGAGTCCATAATTACTACAGAAACAAAGAGT } \\
\text { AAAATGAGATTCTTC }\end{array}$ \\
\hline 44259 & $\begin{array}{l}\text { AATTCTCCGATGATTGCCCGTTCGTGAATCTGGGTTTGAATTCTGCCGCATTCTCTGTTGATTCGTGTTTCGGTGGACCA } \\
\text { GATTTGATTTCTGAG }\end{array}$ \\
\hline
\end{tabular}


Table B4.2. Consensus 95bp sequence for discriminate analysis of principal components informative loci.-Continued

\begin{tabular}{|c|c|}
\hline Locus & Sequence \\
\hline 47505 & $\begin{array}{l}\text { AATTCCGCTAACGCTTGCGCTGAATAAAACTGAACTTGTTGATGAAGAGGTTCGAACAACTTCTCAACACTATCTGCA } \\
\text { CTTAGTTCTTGAGCTAG }\end{array}$ \\
\hline 53441 & $\begin{array}{l}\text { AATTCAGAGGTCAATGCTGCCAAGTGTGCAAGGCCAGGAAGAAGGAAAGTGGGTTGTGGTTGATTCAGGTCTGTGCT } \\
\text { CTTCCATCCATTTGGCTA }\end{array}$ \\
\hline 54384 & $\begin{array}{l}\text { AATTCGAAAGGACAAGGGGTTGTTCATGGATCATCAATGTATATTGGTTTTCACAAGAGAGGATAGATAGATATAGATAC } \\
\text { AGTCATGAATCTTTT }\end{array}$ \\
\hline 62956 & $\begin{array}{l}\text { AATTCTGGCGATTCAGGGTGTAGACGAAGTAAGGTCTGTTGGAGAGACATAGTTTGCAGGATTTGTGATGGATTACGCT } \\
\text { GGTGCATCAGACAGTA }\end{array}$ \\
\hline 11136 & $\begin{array}{l}\text { AATTCAGATGAATACAATGCAAACTAATTTGCTGTGAAAATACCGCAACAGGTAAAAGTGAGGGGATATGCAGTATCA } \\
\text { GGAGGCGGCCGTGGTAT }\end{array}$ \\
\hline 14084 & $\begin{array}{l}\text { AATTCTCTCTCTCGCTATCTCAAGATTTACACAAGTAGGAGACTCTTTGTGATCGTTGATGATGCTCCTCAGTTCTTTCG } \\
\text { TAGTTTTGTGGCAAG }\end{array}$ \\
\hline 18527 & $\begin{array}{l}\text { AATTCTTTGCCTTGGTTGTGCTAGGAGCTAGTCCTTAGCAAGGCTAGTTCTCCAAAATCATTCTATTTGTTTGAATGAAT } \\
\text { TGCACTTGAGGTCTT }\end{array}$ \\
\hline 24703 & $\begin{array}{l}\text { AATTCCCTGCCCCCCAAATGAATCATACGGATCATCACCATCAGGCCTTCCTTGGCCCCCATCTTTGTCAGATGGCATGT } \\
\text { CACCTCCCTGTGGAT }\end{array}$ \\
\hline 42124 & $\begin{array}{l}\text { AATTCCCTAAATTAGAGTGCATAAAAATACGATTGCGGAGCAGAAATTGGATAACGAATTGATACCTAGAAATTGACTT } \\
\text { GCTGATGTCGGGGAAA }\end{array}$ \\
\hline
\end{tabular}


For more information concerning the research in this report, contact the

Director, Western Ecological Research Center

U.S. Geological Survey

3020 State University Drive East

Sacramento, California 95819

https://www.usgs.gov/centers/werc

Publishing support provided by the U.S. Geological Survey

Science Publishing Network, Sacramento Publishing Service Center 
